Illinois State University

ISU ReD: Research and eData

Theses and Dissertations

10-13-2014

\title{
Troubled Waters: Security, Economic Development, And The Senkaku/diaoyu Islands.
}

Kevin McKenzie

Illinois State University, kevin.m.mckenzie@gmail.com

Follow this and additional works at: https://ir.library.illinoisstate.edu/etd

Part of the History Commons, Peace and Conflict Studies Commons, and the Political Science Commons

\section{Recommended Citation}

McKenzie, Kevin, "Troubled Waters: Security, Economic Development, And The Senkaku/diaoyu Islands." (2014). Theses and Dissertations. 277.

https://ir.library.illinoisstate.edu/etd/277

This Thesis is brought to you for free and open access by ISU ReD: Research and eData. It has been accepted for inclusion in Theses and Dissertations by an authorized administrator of ISU ReD: Research and eData. For more information, please contact ISUReD@ilstu.edu. 


\title{
TROUBLED WATERS: SECURITY, ECONOMIC DEVELOPMENT, AND THE SENKAKU/DIAOYU ISLANDS
}

\author{
Kevin McKenzie
}

118 Pages

December 2014

This project uses a case-study approach to investigate the factors driving the Senkaku/Diaoyu Island dispute between Japan and the People's Republic of China. Drawing on historical and economic evidence, this research explores the role of trade interdependence in shaping the territorial dispute 
TROUBLED WATERS: SECURITY, ECONOMIC DEVELOPMENT, AND THE SENKAKU/DIAOYU ISLANDS

KEVIN MCKENZIE

A Thesis Submitted in Partial Fulfillment of the Requirements for the Degree of

MASTER OF SCIENCE

Department of Politics and Government

ILLINOIS STATE UNIVERSITY 
(C) 2014 Kevin McKenzie 
TROUBLED WATERS: SECURITY, ECONOMIC DEVELOPMENT, AND THE SENKAKU/DIAOYU ISLANDS

KEVIN MCKENZIE

COMMITTEE MEMBERS:

Michaelene Cox, Chair

T.Y. Wang

Sherri Replogle

Louis Perez 


\section{CONTENTS}

CONTENTS

$\begin{array}{ll}\text { FIGURES } & \text { iii }\end{array}$

CHAPTER

I. INTRODUCTION 1

Overview 1

Methods 3

Organization $\quad 6$

$\begin{array}{ll}\text { II. THEORETICAL OVERVIEW } & 7\end{array}$

Regime Insecurity Theory $\quad 8$

$\begin{array}{ll}\text { Liberal Peace Theory } & 12\end{array}$

III. REVIEW OF RELATED LITERATURE 20

Territory 20

Legitimacy 25

Economics $\quad 29$

IV. HISTORICAL CONTEXT 33

Sino-Japanese War 33

The Fishing Expedition $\quad 35$

The First Lighthouse Incident $\quad 39$

The Second Lighthouse Incident 40

2005 Flare-up and the Race for Natural Resources 42

2012 Flare-up and the Nationalization Crisis 44 
V. ECONOMIC CONTEXT 47

Japan: Industry from Ashes 47

China: Newcomer and Giant $\quad 51$

$\begin{array}{ll}\text { Economic Interdependence } & 60\end{array}$

VI. POLITICAL CONTEXT 65

Japanese Politics $\quad 66$

Japanese Political Parties and Factions $\quad 68$

$\begin{array}{ll}\text { Chinese Politics } & 72\end{array}$

$\begin{array}{ll}\text { Competing Nationalists } & 78\end{array}$

$\begin{array}{ll}\text { VII. ANALYSIS } & 87\end{array}$

$\begin{array}{ll}\text { VIII. CONCLUSIONS } & 107\end{array}$

Policy Recommendations $\quad 107$

Openings for Future Research 111

$\begin{array}{ll}\text { Summary } & 112\end{array}$

$\begin{array}{ll}\text { REFERENCES } & 114\end{array}$ 


\section{FIGURES}

Figure

Page

1. Map of East China Sea 34

2. PRC Budgetary Revenue Responds to Reform 54

3. SOE Employment with Estimated Data 55

4. Main Sources of FDI to China 58

5. Total PRC Imports and Exports as Percent of GDP 61

6. China's Balance of Trade with Japan 62

7. Trade Dependency between Japan and China 63

8. Trade Dependency between Japan and China Overlaid with Disputes 100 


\section{CHAPTER I \\ INTRODUCTION}

Overview

Two American B-52 bombers departed Guam on November 25, 2013. Their flight, reportedly part of a long-planned training exercise, was unarmed. At 7PM local time, the bomber wing crossed into the Chinese military's Air Defense Identification Zone (ADIZ), unilaterally imposed just two days prior, overlapping both the South Korean and Japanese aerial cordons. ${ }^{1}$ As they flew over the Senkaku Islands, known as the Diaoyu in mainland China and the Diaoyutai to Taiwan, the American aircrews were determining Beijing's intentions. In declaring their aerial cordon over the contested islands, China required passing civil and military aircraft to identify themselves and obey instructions of the Chinese Ministry of National Defense. Noncompliance would be met with vaguely defined "defensive emergency measures" as far as 130KM into the East China Sea. ${ }^{2}$ In traversing the zone, the American bombers determined just what China would do to respond to violations of its newly expanded territorial markers: nothing, for now.

The establishment of the Chinese ADIZ is the latest escalation in a series of disputes stemming from the Japanese government effectively nationalizing the

\footnotetext{
1 “US Bombers Challenge China's Air Defense Identification Zone," The Diplomat, accessed October 12, 2014, http://thediplomat.com/2013/11/us-bombers-challenge-chinas-air-defense-identification-zone/. 2 "China Imposes Restrictions on Air Space Over Senkaku Islands," The Diplomat, accessed October 12, 2014, http://thediplomat.com/2013/11/china-imposes-restrictions-on-air-space-over-senkaku-islands/.
} 
Senkaku/Diaoyu Islands in 2012. The inhospitable and uninhabited islets, administered by the Japanese since 1895, have been actively disputed by the People's Republic of China (PRC) since the discovery of petroleum reserves nearby in the 1970s. The most recent flare-up of this dispute has led to close encounters under uncertain rules-ofengagement by military aircraft of the world's three largest economies, two of them nuclear armed. As time passes without a diplomatic settlement of the dispute, the risk for miscalculation or accidental escalation increases, and the stakes could not be higher.

The International Monetary Fund predicts that fully twenty-five percent of global economic growth will occur in China over the coming decade. ${ }^{3}$ East Asia, and Northeast Asia in particular, is poised to re-center global productivity, with the region experiencing unprecedented economic dynamism. These leaps in development disrupt the balance of power undergirding a tenuous if longstanding peace. New economic realities translate into new military capabilities for developing nations. The security situation in the region is dangerous, with the world's highest concentration of lethal military force. ${ }^{4}$ Three of the original five permanent members of the UN Security Council maintain permanent bases there, all of them nuclear armed. Flashpoints are numerous, and Asia has the dubious distinction of housing the world's highest concentration of divided states. The violence of the Pacific War and subsequent bad relations poison efforts at reconciliation, and nowhere is that heritage more acrimonious than between Japan and China, the region's leading powers. ${ }^{5}$

\footnotetext{
3 “Country and Region Specific Forecasts and Data," accessed October 12, 2014, http://www.worldbank.org/en/publication/global-economic-prospects/data.

${ }^{4}$ T. J. Pempel, The Economy-Security Nexus in Northeast Asia (Routledge, 2013), 2.

${ }^{5}$ Also known as the Pacific Theater of World War II in the United States and Europe.
} 
This project seeks to explain the Senkaku/Diaoyu dispute with an eye toward possible solutions. At its most elementary level, the dispute stems from the Japanese acquisition of the uninhabited islets following the Sino-Japanese War of 1895. As the provenance of this acquisition is hotly disputed, the historical roots of the conflict will offer a baseline of context for considering the territorial dispute. Economic growth proceeds unabated, redefining the regional and global balance of power in favor of the developing nations of East Asia, most particularly China. In investigating the fraught relationship between the Chinese and Japanese government, it is important to note that each nation represents the other's largest or second largest trading partner. With theoretical backing, we will analyze the effects of economic interaction on territorial disputes in this dyad. Given the Chinese and Japanese governments' continued conflict despite a professed focus on economic development, economics will not solely explain the Senkaku dispute. To round out this analysis, political systems and developments will be considered to determine possible agitants to inter-Asian relations. This project will add to the understanding of the Senkaku Dispute literature by carrying existing economic analyses one step further, investigating possible political obstacles to the formation of trade-based cooperation.

\section{Methods}

This study employs a case-study method, analyzing each of the six major Senkaku/Diaoyu disputes between 1970 and 2013. Historical details are confirmed through multiple sources wherever possible, as the issues discussed are substantially disputed by competing chronologies. Economic data provides a broad picture of the developing relationship between Japan and China, belying the difficult diplomatic 
environment. We will consider trade throughput and trade dependency between the two nations for additional context into the conflict. As the conflict persists despite intense economic entanglement, this study will also consider political systems and popular groups, in particular comparing nationalist organizations. As case-studies form the basis of our argument, the results will not be generalizable, but rather will specifically describe the relationship between China and Japan. Further, this method does not suggest causality, leaving room for alternate explanations for the events and phenomena described.

This project relies on a two-part hypothesis. The first hypothesis is concerned with the perception of regime security by policymakers in China.

$\mathrm{H}_{1}$ : As China is more secure, there will be more severe conflict over the Senkaku/Diaoyu islands.

Here, China's security is measured by its economic vitality, specifically in its gross domestic product (GDP) per capita. In keeping with regime insecurity theory, security will be considered as a regime's safety from internal and external challengers to power. As China devotes a substantial portion of its fast-rising GDP to a capable domestic and international security apparatus, this linkage is justified. Further, statements of Chinese policymakers link economic vitality to the maintenance of social order and government control in the domestic sphere.

To measure this hypothesis, individual instances of conflict will be considered according to the list of major Senkaku/Diaoyu Island disputes as recorded by Min Gyo Koo. Severity will be measured on a continuum, with the diplomatic disputes being 
separated into three categories. Flare-ups of the dispute without substantial violent protests in China or Japan and lacking related military posturing will be classified as minor. Disputes which progress into substantial violent protests or an escalation of military posturing will be classified as moderate. Open, armed conflict between China and Japan (or allied powers) over the islands will be classified as a severe dispute. Measures of severity will be confirmed by the mention of non-isolated incidents of violence during protests in reputable, international media sources. Reputable international media reports will also be used to define Chinese or Japanese military operations as being linked to the dispute.

The second hypothesis concerns the economic interdependence between China and Japan.

$\mathrm{H}_{2}$ : As China and Japan become more economically interdependent, conflict will be less severe over the Senkaku/Diaoyu Islands.

In keeping with liberal peace theory, trade likely plays a restraining role in Sino-Japanese relations. To measure this expectation, trade dependency will be used as a metric of economic entanglement. Trade dependency will be measured as the sum of imports and exports from a given country, divided by the GDP of the country of study. This statistic will be measured for both China and Japan. Severity of conflict over the islands will retain the same definition as in the first hypothesis.

Taken in tandem, these two hypotheses offer a formal statement of the expectations of this project. A number of factors drive the Senkaku dispute, with economics providing a linkage between disparate influences, such as the electoral politics 
of Japan or the domestic power struggles of China. Prosperity has empowered the Chinese state, allowing it to pursue policies to secure itself internationally. As the relative threat of international actors wanes for China, an incentive for cooperation disappears. The comparative gains of domestic legitimacy to be had in raising old territorial disagreements are thus more appealing. Paradoxically, the international trade which has lent to this economic empowerment also represents one of the few remaining restraints against belligerent policymaking in the region. Our hypotheses are structured to reflect the complex relationship between prosperity and cooperation in this dyad.

\section{Organization}

We begin this discussion with a summary of major theoretical works which explain the relationship between economics, regime security, and peace. A broad review of related literature of the Senkaku/Diaoyu dispute follows, organized into clusters by the author's opinion of the primary root of the dispute. The fourth chapter of this discussion, the history section, will offer a chronological report of island flare-ups and major diplomatic developments between 1970 and 2013. The fifth chapter focuses on economic systems and trade, reporting on the form and comparative size of related economies. The sixth chapter offers a brief description of political systems, including recent developments in government for both China and Japan, with a special focus on the acceptance of nationalist sentiments. The seventh chapter analyzes the body of historical and statistical evidence and applies it to answering our hypotheses. The eighth and final chapter offers policy suggestions and concluding comments on the Senkaku dispute. 


\section{CHAPTER II}

\section{THEORETICAL OVERVIEW}

The theoretical basis of this project seeks to explain the Senkaku/Diaoyu dispute. No simple and satisfactory explanation for the persistence of the dispute exists. The conflict is a puzzle due to the insignificant value of the disputed land, particularly when weighed against the vital regional trade ties that the dispute endangers. As such, this project will consider regime insecurity theory and liberal peace theory as theoretical lenses for interpreting the conflict. Of principal importance will be the perception of regime security. Given the massive flux of power into East Asia since the end of the Cold War, as represented by economic and military growth, regional governments now face novel challenges in governance. With a flexible and adaptive parliamentary democracy, Japan has experienced frequent cabinet changes, hardly a challenge to the governing system. For China, the result is a changing sense of risk, not only to individual leadership cadres, but to the governing system of the Chinese Communist Party itself. We will consider how this perception of risk fuels an otherwise perplexing record of Chinese government policies, oscillating between international cooperation and strident refutation of diplomatic norms. To start our discussion, we will consider the role of insecure regimes in addressing international disputes. 


\section{Regime Insecurity Theory}

To explain the regime insecurity framework, we begin by considering what is at stake in international disputes. As China is the nation reacting most severely to the perception of insecurity, authoritarian governments will be the focus of analysis. China, with its economic power on the rise, is insulated against foreign threats. As such, China has room to maneuver internationally, with no proximal and equivalent opponent to constrain it. Raising tensions then would cost the Chinese government little, and offer domestic payoffs. In the study of developing nation governance, a group in power balancing against the most pressing foreign or domestic threat is referred to as omnibalancing. While a government might seek to ward off a foreign power, particularly one with outstanding territorial disagreements, cooperation might be the best technique to entrench the existing government at home. M. Taylor Fravel offers up several possible factors influencing the deployment of omni-balance.

In the face of serious internal threats, often the most serious challengers to authoritarian regimes, Fravel describes the advantages of international cooperation. The first advantage is the possibility of material advantages, such as denying insurgent factions physical resources or a source of legitimacy. Along the border of the far provinces of China, where neighboring nations are more reflective of the local ethnic balance than the coastal center in Beijing, this motivation is particularly pronounced. The second advantage is to free up resources from defending borders from external intrusion for addressing internal resistance. This creates an incentive for cooperation, even if only momentarily, during periods of great unrest, such as the early 1990s challenge which ended in the Tiananmen Square massacre. The third advantage is the enhanced legitimacy 
a government enjoys when it gains international recognition, a credential denied to domestic opponents. ${ }^{6}$ Fravel sums up the motivations for their apparent paradox:

When leaders face internal threats, they may also cooperate to enhance their external security and preempt potential attempts by other states to profit from their domestic woes. These effects of regime insecurity are paradoxical: efforts to consolidate political power at home, often through repression, produce efforts to cooperate abroad. While such behavior is peaceful, its source is not necessarily benign. ${ }^{7}$

These inducements determine the cost and benefit perception for leadership cadres. Ultimately, a government can take three basic stances to respond to territorial disputes. The government can accelerate the dispute, pressing the claim more vigorously or incorporating military force. Risk is high in pursuing military force, however, endangering the aggressor's domestic legitimacy in the case of failure. Even success is risky, as international accession to the new territorial status quo is far from assured. The government can concede the disputed territory, perhaps in exchange for treaty-negotiated perks or joint sovereignty. Obviously, this carries large costs to domestic legitimacy. In China, where government-led historical discussions focus on past unequal-treaties and Nationalist Party collaboration with the imperial Japanese, the cost of hard compromises are particularly unpalatable. ${ }^{8}$ The final general strategy is to delay, claiming sovereignty in public pronouncements, but not moving to settle the dispute. Delaying also has its costs, but mostly external.

\footnotetext{
${ }^{6}$ M. Taylor Fravel, "Regime Insecurity and International Cooperation: Explaining China's Compromises in Territorial Disputes," International Security, 2005. 52.

${ }^{7}$ Ibid.., 52.

${ }^{8}$ Ibid., 53.
} 
The delaying strategy as a negotiating technique allows domestic consolidation at the price international provocation. In the Chinese case, the former is of paramount importance, while the ostensible costs of the latter are weighed as acceptable. By leaving territorial disputes open, the Communist regime can maneuver for maximally favorable terms while running little risk of domestic disruption. In the event of risks to internal hegemony over China, the leadership clique can adopt a conciliatory holding position, to minimize the negative diplomatic effects of an ongoing dispute. ${ }^{9}$ This strategy allows for the issue to be reopened when conditions are favorable, giving the Chinese government little incentive to definitively compromise on disputes. To bolster domestic support by rallying to the flag and off-balancing other possible claimants to domestic legitimacy (namely Taiwan), the PRC can also vituperate during the delay, raising regional nationalist sentiments to bolster home support.

It is important to note special limitations for considering Communist China as a rational, risk-parsing regime with a focus on maintaining domestic hegemony. During certain historical events that effect governmental control over governance, regime insecurity theory does not offer accurate behavioral predications, such as during the Cultural Revolution. One leadership faction undertook the radical agrarian and economic reforms without expectation that it would create vulnerabilities to domestic challenge. By the time those vulnerabilities surfaced, much of the government had ceased to function, including the often-distrusted Foreign Ministry. ${ }^{10}$ As such, land disputes during this unique historical event, characterized by chaos in governance and low-intensity civil war, do not follow the regime insecurity mold.

\footnotetext{
${ }^{9}$ Ibid., 54.

${ }^{10}$ Ibid., 63.
} 
Regime instability theory makes constant reference to the relative power of competing states to understand a given government's interactions with the outside world. This power can be expressed militarily, but can also be comprised of other factors that may give a nation influence over another. Economic growth is one engine which propels states toward positions of dominance over one another. This growth is also a principal cause for cooperation, as in many instances conflict disrupts trade. ${ }^{11}$ The stability of governments (and China in particular for this study) is influenced by their economic performance, making cooperation doubly important. Fravel theorizes that uneven economic growth can create incentives for violent challenges to regional order. ${ }^{12}$ Economic growth is only one measure of regime security, and Fravel points to sharp increases in internal security spending in China as a sign of domestic threats being considered the greatest to regime security there. ${ }^{13}$

In cases of good economic performance, and subsequently high power, regime insecurity theory predicts a more vocal assertion of disputed territorial claims. This is theoretically complicated in China's case, as some of the disputed territories are currently administered by Japan, a nation which contributes substantially to China's economic growth. To parse out these contradictions, we will lean on the wider theoretical discussion of economics in international cooperation.

\footnotetext{
${ }^{11}$ Ibid., 53.

${ }^{12}$ M. Taylor Fravel, "Economic Growth, Regime Insecurity, and Military Strategy: Explaining the Rise of Noncombat Operations in China," Asian Security 7, no. 3 (September 2011): 177-200, doi:10.1080/14799855.2011.615080, 179.

${ }^{13}$ Ibid., 194.
} 


\section{Liberal Peace Theory}

According the liberal peace theorists, economic entanglement is a central driver of cooperative behavior between states. As the value of trade ties increases, the comparative risk of belligerent behavior becomes less appealing. In this study, mutually beneficial trade will be weighed for its impact on individual economies to observe for a possible pacifying effect. Economic inhibitors to war are central to liberal peace theory, but only one of several layers of analysis. We will begin at the most basic level and work our way to economic systems.

The basis for liberal peace stems from common philosophical antecedents which are important to recognize distinctly. For instance, at the individual level, the Hobbesian description of man's natural state provides the impetus for organizing a government. According the Hobbes, men individually possess equivalent power, and without law there is no disincentive to preemptive violence. ${ }^{14}$ The resultant natural system is anarchic, with men insecure in their wealth and unable to gain the benefits of collective labor. A selfish desire for personal wealth leads individuals to cede liberty to rulers, either despots or republics, to create a framework for secure and prosperous living. This individual level desire for security is extended to an assumption of an individual desire for peace.

These individual level desires are transformed into governmental prerogatives through a series of relationships described by Morasevic in Taking Preferences Seriously. Not all Hobbesian assumptions can be extended to governmental behavior; for instance, a government does not fear the risk of violence in the same manner as an individual. A

\footnotetext{
${ }^{14}$ Newbrander, David, "Liberal Peace: A Dyad of Democray and Economic Interdependence, Grounded in Agent Desires," The Monitor Journal of International Studies 18, no. 1 (2012), 35.
} 
government does, however, respond to inducements like an individual. Through intermediary representative institutions, a government seeks to maintain power by answering citizen calls to action. ${ }^{15}$ Ignoring these calls is costly, even for an authoritarian regime. It is important to note that all groups are not necessarily equal within a representative institution. With this inherent inequality of forces, a rational profitmaximizing approach does not inevitably prevail. Actions are determined by pressure from most dominant groups within government. ${ }^{16}$

This pattern of behaviors explains why nations may fight over contested land, despite an acknowledged preference of individuals toward peace. A government seeks to maximize rewards for its own citizens, but carries separate decision criteria from the individuals. Peace is not a mandate of successful representation in the Hobbesian model. ${ }^{17}$ Liberal peace theorists point to other interlocking tendencies of government to explain a perceived increase in cooperative behavior over time. For instance, forms of government matter. As conflict arises from an incompatibility of preferences, common ground reduces the instance of conflict. Democracies are thus predicted to war with one another less frequently. By the same token, economically interdependent nations are less likely to risk their trade ties for the possibility of war spoils down the road. ${ }^{18}$

The question of frequency is central to Morasevic's contribution to the body of liberal peace literature. Of course, counterpoint examples of aggressive democracies and restrained autocracies abound. This is particularly important when considering

\footnotetext{
${ }^{15}$ Andrew Moravcsik, "Taking Preferences Seriously: A Liberal Theory of International Politics," International Organization, 1997, 519.

${ }^{16}$ Ibid., 520.

${ }^{17}$ Newbrander, David, "Liberal Peace: A Dyad of Democray and Economic Interdependence, Grounded in Agent Desires." 39.

${ }^{18}$ Ibid., 39.
} 
Communist China, which despite much saber-rattling and showmanship has not engaged in a ground war since its 1979 invasion of Vietnam. In Morasevic's view, this probabilistic tendency of economic partners and democracies to avoid warfare is a function of systems rather than good intent. Autocratic governments, lacking the representative institutions and safeguards of the republics, wield power more arbitrarily. ${ }^{19}$ As such, a wider range of behaviors can be expected from autocracies. This unpredictability leads to autocracies, on average, engaging in more conflicts than their representative counterparts.

Particularly among republican governments, certain ideological and structural forms are suggested as inhibitors to belligerence. A common ethical basis at the individual level, stemming from a tendency of republican citizens to avoid bloodshed to solve domestic matters, extends to the international level through representative institutions. Governing structure also contributes to the prediction of fewer wars among the republics, as a broad-based decision-making process involves more self-interested voices who are averse to risking themselves in international violence. ${ }^{20}$

This broad basis of public support, stemming from majoritarian rule, is a focus of Kant's republic, another philosophical basis for liberal peace theory. It is important to note that this so-called republic describes the result rather than the system: Kant's republic could be a responsive constitutional monarchy, or any number of systems other than a modern representative democracy. The important qualifying factors which make a government republican in the Kantian sense are as follows: individual freedom, rule of

\footnotetext{
${ }^{19}$ Moravcsik, "Taking Preferences Seriously." 532.

${ }^{20}$ Ibid., 40.
} 
law, and the citizens' assent to legal coercion. ${ }^{21}$ This non-normative form of government sets a framework for citizens to coexist in, intervening only where individuals infringe on one another's liberties and only then in accordance with the law. These factors influence the likelihood of war by enshrining liberal individual actions as a framework for government. A group of such nations respond to selfish individual impulses toward nonaggression, thus creating safety through homogeneity.

A modern, concise summary of liberal peace theory exists in Michael Doyle's "Three Pillars of the Liberal Peace". The core precepts are drawn from Kant's "Perpetual Peace" published in 1795, and the relationship is demonstrated in the titular three pillars. These key factors which discourage conflict between liberal states are as follows: republican representation, respect of human rights, and transnational interdependence. ${ }^{22}$

The three pillars work in tandem, but not separately, to explain the tendency of liberal states to avoid war with one another. As described previously, liberal peace presumes that individuals prefer peace, with its low risks and personal prosperity. In an accountable democracy, the median voter is well represented, whereas despotism relies on a much smaller body of sometimes unreliable decision-makers. Democratic rulers who engage in risky behavior, such as bluffing or brash aggression, face electoral defeat. Additionally, a representative system governed by published rules does much dispel uncertainty in the behavior of states. This tendency towards relatively clear signaling,

\footnotetext{
${ }^{21}$ Vesna Danilovic and Joe Clare, "The Kantian Liberal Peace (Revisited)," American Journal of Political Science 51, no. 2 (April 2007): 397-414, doi:10.1111/j.1540-5907.2007.00258.x, 400.

${ }^{22}$ Michael W. Doyle, "Three Pillars of the Liberal Peace," The American Political Science Review, 2005. 463.
} 
referred to by Kant as republican "publicity," decreases the odds of international misinterpretation of risks that might lead to conflict. ${ }^{23}$

In describing the behavior of liberal states toward one another, Doyle makes an important distinction lacking in other prominent works on liberal peace theory. Where individual preferences transform into state preferences, liberal state citizens are described as perceiving other liberal state citizens as morally similar and guided by the same rules, and thus the citizens encourage their government toward positive interaction with liberal states. The opposite is true of liberal state citizens regarding illiberal states: they presume untrustworthiness, and thus encourage their governments to keep their distance, or worse, act belligerently. This is a large break from other theorists, and is important for consideration given the liberal/illiberal dyad represented in the Senkaku dispute.

The final pillar, economic interdependence, is a central concern of this study. Described by Kant as a pacifying "spirit of commerce," economic entanglement between liberal states produces material disincentives toward engaging in conflict. ${ }^{24}$ Under mutually beneficial conditions governed by established laws and protocols, liberal states can jointly achieve greater prosperity than had by states in autarky. ${ }^{25}$ Additionally, market forces manage complex and periodically damaging decisions required for resource optimization. As a result, states do not fully control their prosperity and thus can be insulated from belligerent feelings generated by market shocks.

In terms of economic interdependence with between liberal and illiberal states, Doyle offers the example of colonial rule. In this example, the trade between a liberal

\footnotetext{
${ }^{23}$ Ibid., 464

${ }^{24}$ Ibid., 465.

${ }^{25}$ Ibid., 466.
} 
state and an illiberal one is presumed to generate conflict, due to physical insecurity and uncertain legal safeties. ${ }^{26}$ This is one possible economic relationship between a liberal and illiberal state, but perhaps less relevant to the majority of modern trading dyads. Few illiberal states can plausibly fear plunder by previous liberal colonial masters. So, in his final analysis that economic interdependence increases the risk of strife between liberal and illiberal states, Doyle offers one particular case as a general rule that may no longer be generally applicable.

The general point of Doyle's economic theory is important for Sino-Japanese relations. Particularly where improved ties and cooperation are being sought through increased economic throughput, it is important to consider the Kantian basis for economic interdependence leading to greater cooperation. Where mutual benefit is perceived, as in the majority of interactions where Japanese and Chinese businesses meet one another's expectations of propriety, economic entanglement improves relations. In the event of complications, such as in the relatively rare event of government interference or popular nationalist boycotts, economic entanglement is another cause for friction in international relations.

In short, there are diverse viewpoints within the academic discourse of liberal peace. As a descriptor of global changes to the world international system over time, Morasevic observes a general trend toward greater economic entanglement. While he singles out the liberal democracies as enjoying historically unprecedented cooperation, the process coincides with a rapid expansion of the democratic franchise. As such, economic relationships do not endanger the peace. Danilovic and Clare run regression

\footnotetext{
${ }^{26}$ Ibid., 466.
} 
analysis to similar results, albeit with different details. According to the researchers, while a plurality of political disputes involves at least one liberal party, military confrontations involving liberal states are quite rare, accounting for fewer than 17 percent of armed conflicts. ${ }^{27}$ These results fly in the face of economic success exacerbating conflict, as liberal powers have outsized economic influence. ${ }^{28}$ Described previously, Doyle supposes that the composition of the trading dyad determines its effect. Using a particular historical circumstance, namely the rise of mercantilism, Doyle argues that liberal and illiberal partners do not share sufficient normative structures to ensure trading will go well and improve relations. Thus, the value of economic interdependence is uncertain, and its war-preventing qualities are lost.

In considering the theoretical framework of territorial disputes involving China, a complex system emerges. Regime insecurity theory offers a compelling system of analysis, seeking to explain when governments press their claims as opposed to accepting compromise. While the PRC does not currently seek expansion beyond old Qing Dynasty antecedents, the currently claimed territory is sufficiently critical to endanger regional stability. Economics will likely play a restraining role as suggested by liberal peace theorists, but it is unclear to what extent the PRC views uncontrolled foreign trade as a resource. Equally worrisome, with a tight grip on domestic media access, Chinese government authorities leverage ongoing disputes to stoke anti-foreign sentiments. This fulfills near-term goals of the PRC, stymying possible challengers to governance by focusing attention outward, in keeping with the general outlines for regime insecurity set

\footnotetext{
27 Danilovic and Clare, "The Kantian Liberal Peace (Revisited)," 408.

${ }^{28}$ Edward D. Mansfield, Helen V. Milner, and B. Peter Rosendorff, "Free to Trade: Democracies, Autocracies, and International Trade," The American Political Science Review, 2000, 314.
} 
out by Fravel. However, media manipulation is a double-edged sword, as the animosities generated and kept at the forefront of public attention are very real. PRC policies lay the groundwork for a future where the cost to domestic legitimacy of inaction may be considered equal to the international risk of military action. With these theoretical frameworks in mind, we will consider existing scholarship on the roots of the island dispute in question. 


\section{CHAPTER III REVIEW OF RELATED LITERATURE}

The Senkaku/Diaoyu dispute is contested at its most basic levels by the involved parties. Academic thinkers from a variety of disciplines analyze the dispute in the hopes of penetrating the sometimes opaque motivations of the involved nations. Among observers of regional security in East Asia, there are a multitude of interpretations of the conflict. Multiple broad arguments figure prominently in the existing literature. We will consider the full diversity of these arguments, with author's grouped by their view of the primary driver of the Senkaku dispute.

\section{Territory}

The first group of argument is that the primary cause for the conflict is a genuine territorial dispute. Authors comment on the intractably different interpretations of recent history expressed by China and Japan. Broadly, this camp sees the conflict as a result of political systems and territory, rather than a conflict over resources. In the "Chinese Leadership Monitor,” Michael Swaine proposes that new CCP leadership under Xi Jinping consider the Senkaku islets only slightly less important than Taiwan as a geopolitical goal. ${ }^{29}$ This is at once alarming and reassuring: on the one hand, the islands are widely considered Japanese as part of the present status quo, and thus a unilateral

\footnotetext{
${ }^{29}$ Michael D. Swaine, "Chinese Views Regarding the Senkaku/Diaoyu Islands Dispute," China Leadership Monitor, no. 41 (Spring 2013): 1, 40.
} 
competitive claim is vexing to regional cooperation. This is particularly destabilizing with the inclusion of military overflights by the Chinese military. On the other hand, stated Chinese policy leaves room for an honorable withdrawal by classifying the Senkaku islets at a lower tier of importance than Xinjiang, Tibet, or Taiwan. The dispute serves as an agitant outside of the economic sphere, precluding closer relations based on trade. The icons of increased cooperation, namely factories manufacturing products for Japanese brands in China, were targeted during substantial unrest in 2012 and 2013.

Legal scholars theorize over formative differences between capitalist and communist states after World War II, which survive institutionally into the present day. The author Roda Mushkat discusses the perception of two tracks of international law in the postwar environment: one set of laws amongst socialist countries, and then a separate set of laws international laws for capitalist countries. The communist bloc saw international law as fundamentally hostile and in favor of entrenched capitalist interests. ${ }^{30}$ In this adversarial context, communist nations developed uncommonly aggressive negotiating tactics, as internationally mediated solutions were considered rigged.

In the Chinese case, this legal preference is reinforced by a tumultuous history. The Unequal Treaties with colonial powers played a substantial role in the Century of Humiliation, a historical precedent that is thoroughly studied by Chinese policymakers. The authors claim that this historical background is decisive in creating an air of ambivalence in China with regards to international mediation of territorial disputes. Sovereign freedom-to-maneuver is considered paramount to policymakers, with armed

\footnotetext{
${ }^{30}$ Roda Mushkat, "Chinese Border Disputes Revisited: Toward a Better Interdisciplinary Synthesis [article]," Richmond Journal of Global Law and Business, no. 1 (2012): 45, 51.
} 
conflict being an acceptable recourse to settle or extend disputes. ${ }^{31}$ While pragmatic considerations of strategy allow certain disputes to be resolved with peaceful expedience, this outlook generally causes territorial disputes to be lengthy and contentious.

Authors from mainland Chinese institutions tend to follow a legal formula as well. It is important to note that open academic exchange is heavily circumscribed in the PRC, and these are the views which survived that culling process. In the tellingly named The Unhelpfulness of Treaty Law in Solving the Sino-Japan Sovereignty Dispute over the Diaoyu Islands, scholar Chi Manjiao describes the perceived legitimacy of multiple treaties reapportioning territory after the war in the Pacific. These include the Treaty of Shimonoseki in 1895, the Treaty of San Francisco in 1951, and the separate peace treaties between Japan, Taiwan, and China. The author's central argument is that formal agreements shaping the postwar boundaries of Pacific nations unfairly favor the Japanese and create a framework for ongoing struggle that fuels international tensions. ${ }^{32}$ Central to this reading is the long-running dispute over the unlikely, uninhabited Diaoyu islands.

The author reiterates the importance of the Treaty of San Francisco as an example of exclusive international agreements which disadvantage mainland China. Neither the People's Republic of China nor the Republic of China was invited to participate due to disagreements stemming from their ongoing civil war. Despite highly advantageous results for Chinese sovereignty, the treaty thus has a pall cast over it by the specter of the Unequal Treaties. The absence of a Taiwanese protest over the Treaty of San Francisco is described, in a jab at Taiwanese legitimacy, as a product of American trusteeship and

\footnotetext{
${ }^{31}$ Ibid., 53.

${ }^{32}$ Chi Manjiao, "The Unhelpfulness of Treaty Law in Solving the Sino-Japan Sovereign Dispute over the Diaoyu Islands," East Asia Law Review 6 (October 1, 2011): 163, 174.
} 
ostensible domination. The mainland Chinese lodged vociferous protests, decrying the treaty as a unilateral American intervention, in the style of Revolutionary China's attack diplomacy. ${ }^{33}$ In this manner, mainland Chinese scholars explain their claims as having greater gravity than either Japan or Taiwan, due to continuous contests by the communist government.

While multiple mainland authors follow this general line of treaty-based argument, the authors offer a diverse variety of solutions. Chi Manjiao presciently describes the island dispute as a substantial hindrance to important international relationships, namely with Japan and the United States. As these are China's two largest trading partners, the importance of the relationship is not overstated. The author suggests that the issue should be resolved, and quickly, although they make no suggestion of concessions. Other writers fall in line with the tone set by the mainland, state-run media. Gao Jianjun discusses the same base treaties, detailing Chinese records of interaction with the disputed islands. From this baseline of evidence, Gao repeats the governmental claim that the islands are illegally held by the Japanese, and that Chinese sovereignty is being unfairly restricted. ${ }^{34}$ This falls in line with the Chinese government course of action, such as the unilateral establishment of armed military patrols in the airspace of the disputed islands, which is informed by the assumption of preexisting sovereignty.

One mainland author adds an additional corollary to the familiar claims of Chinese sovereignty. Zhongqi Pan offers a detailed analysis of the treaty basis for

\footnotetext{
33 Ibid., 170.

${ }^{34}$ Gao Jianjun, "The Territorial Status of the Diaoyu Islands in 1895: A Crucial Issue for the Dispute over These Islands," Social Sciences in China 31, no. 4 (November 2010): 106-17, doi:10.1080/02529203.2010.534677, 115.
} 
Japanese control of the disputed islands. The author cites antiquities sources that reference the Diaoyu islands as an imperial holding of the Qing dynasty, although uninhabited. Zhongqi Pan also cites Japanese academic Inoue Kiyoshi’s work, a sympathetic communist voice, offering similar evidence. While these arguments are familiar, the author offers a mainland interpretation of the risks of concessions to China's goal of annexing Taiwan. As China views the disputed islands as affiliated with the Taiwanese island chain (as does the Taiwanese government), to offer concessions to either Japan or Taiwan is seen as dangerous to the PRC's eventual goal of unification, a long-held core interest of the Chinese Communist Party. Zhongqi Pan offers the following analysis, based in PRC policy which regards Taiwan as only temporarily an independent political body:

China's softening of its posture on the dispute over the islands with Japan would not only endanger its claim to the islands themselves, but also jeopardize its claim to Taiwan by sending wrong signals toward separatist forces in Taiwan that seek independence. ${ }^{35}$

This offers some explanation for the intractability of Chinese claims to the uninhabited islets, and the seemingly disproportionate risks taken by militarily pressing those claims.

Other authors point to a long pattern of territorial expansion and tribute reaching into Chinese antiquity as an indicator of core motivations. In his key volume On China, Henry Kissinger looks to imperial antecedents as the building blocks of contemporary Chinese foreign policy. During the late Qing Empire, China fell behind western powers and ultimately regional forces such as Meiji Japan. Crippling losses, such as the capture

\footnotetext{
${ }^{35}$ Zhongqi Pan, "Sino-Japanese Dispute over the Diaoyu/Senkaku Islands: The Pending Controversy from the Chinese Perspective," Journal of Chinese Political Science 12, no. 1 (March 2007): 71-92, doi:10.1007/s11366-007-9002-6, 86.
} 
of Southeast Asia by western powers or large island holdings like Formosa and the Ryukyus by imperial Japan, were seen as temporary set-backs to a culturally superior empire. $^{36}$

In seizing indefensible islands from Taiwan in the 1950s, Revolutionary China followed the imperial precedent of reclaiming territory after its borders fluctuated. Mao Zedong described the military operation, checked by the American Seventh Fleet prior to the Taiwanese main islands, as a means to discomfort his Nationalist adversaries and leave the dispute open for the future. ${ }^{37}$ This pattern of leaving disputes unresolved until favorable conditions arise is described as a holdover from Confucian "barbarian management," or foreign affairs. Absent notable pragmatists, such as Deng Xiaoping who Kissinger interacts with extensively during a period of great Chinese vulnerability, the outlook is described as dim for international cooperation. This view raises particular concerns given the extensive list of Chinese territorial disputes, covering most its farranging land border and myriad islands distant from the mainland.

\section{Legitimacy}

Another school of thought attributes the conflict to internal political struggles. Included in this interpretation is the theory of regime insecurity fuelling Chinese government policies. Decisions for increased cooperation or belligerence are calculated to preserve the $\mathrm{CCP}$ as the sole power in mainland China. As such, economics do not figure into analysis beyond what minimums are required to maintain domestic legitimacy; as a historical sensitivity to Japanese economic domination preceding

\footnotetext{
${ }^{36}$ Henry Kissinger, On China (New York City, NY: Penguin Press, 2011), 73.

${ }^{37}$ Ibid., 156.
} 
invasion, economic incentives may even draw suspicion from the Chinese leadership clique. In Regime Insecurity and International Compromise, M. Taylor Fravel suggests Chinese foreign policy is more aggressive and less compromising during periods of internal stability.

Fravel links territorial compromise over the course of China's contentious postrevolutionary period to high levels of domestic political instability. ${ }^{38}$ For instance, the Tiananmen Square Movement and later massacre caused Chinese leadership to adopt cautious foreign policies while addressing internal dissenters. The following succinctly sums up the PRC's international reaction to newfound insecurity:

Following the 1989 Tiananmen crisis and worries about the viability of its socialist system, China attempted compromise in disputes with its socialist neighbors the Soviet Union, Laos, and Vietnam; in addition, it reached confidence-building agreements with India and Bhutan. ${ }^{39}$

Similar patterns can be discerned during periods of revolutionary unrest following World War II. This raises troublesome possibilities for the future, as China grows in economic prosperity and authoritarian stability under the direction of the Communist Party. Economic success reduces the perception of external constraints on Chinese government policy.

Fravel draws on earlier work by Chiozza and Goemans on causes of regime instability. Where Fravel comments on the performance of the PRC in the international arena during periods of instability, Chiozza and Goemans offer insight into periods of prosperity. In their quantitative approach, they measure the likelihood of states initiating

\footnotetext{
${ }^{38}$ Fravel, "Regime Insecurity and International Cooperation," 62.

${ }^{39}$ Ibid., 63.
} 
conflict under a number of conditions. Their work affirms the broad strokes of democratic peace theory, citing a preponderance of evidence that democracies initiate conflict less frequently than hybrid or authoritarian regimes. ${ }^{40}$ Interestingly, they add a corollary at odds with the economic underpinnings of liberal peace: as nations experienced economic growth, their leaders enjoyed a higher persistence in office with fewer threats to rule. ${ }^{41}$ This increased legitimacy removes constraints against acting on belligerent preferences. As a result, prosperous states initiated conflict more frequently than destitute ones.

Other authors have also analyzed the PRC's perceptions of legitimacy and international cooperation. Chris Hughes describes the balance struck by Chinese elites between cooperation with Japan for economic growth on the one hand, and demonization of Japan for domestic legitimacy on the other hand. In the revolutionary years, where technological development was low and media control was extremely high, the Chinese government is described as having strong control over public opinion on the issue. While past foreign aggression was emphasized to bolster domestic support at home, that tactic could be balanced with a pragmatic foreign-facing diplomatic front. The contradiction is described in the following passage:

This perpetuation of memories of Japanese aggression has always had a difficult relationship with the requirements of foreign policy. While PRC diplomacy has focused on winning Tokyo's diplomatic and economic support, in domestic politics representations of traumatic events such as the Nanjing Massacre have been used to stir up anti-American patriotism during the Korean War, to

\footnotetext{
${ }^{40}$ Giacomo Chiozza and H. E. Goemans, "Peace through Insecurity: Tenure and International Conflict," The Journal of Conflict Resolution, 2003, 456.

${ }^{41}$ Ibid., 458.
} 
strengthen national pride after the split with the Soviet Union in the 1960s and to discredit the [Guomintang] regime on Taiwan. ${ }^{42}$

This balance could not proceed into the present for a number of reasons. Factions within China vied to use nationalist politics as a foundation for seizing power in a system of winner-take-all authoritarianism. As the stakes were high, with the losers facing ignominious ouster and likely arrest (or worse), playing toward patriotism proved an irresistible if internationally risky strategy. Jiang Zemin, premier during China's opening of the 1990s, was caught in a difficult position. Commercialization of the publishing industry and increased access to foreign media prevented the government from simultaneously seeking foreign allies and demonizing them domestically. ${ }^{43}$ With a popular movement pushing for restitution from Japan for crimes of the midcentury, Jiang had to negotiate opposed forces to maintain power and ensure the nascent economic rejuvenation was not derailed by domestic politics. Ultimately, Jiang suppressed the popular movement for reparations, but delivered highly inflammatory statements on war guilt during the PRC's first visit to Japan by a head of state in 1998. In this system, antiforeign outrage is commodified and played on as a governmental resource. Consider the following as an insider's view of the process:

After the 1989 Tiananmen Massacre and the end of the Cold War, the narrative of resisting Japan was used as a theme of 'patriotic education'. When the newly installed CCP General Secretary, Jiang Zemin, celebrated an exhibition on China's revolutionary history in 1990, he presented the Nanjing Massacre as a valuable example that could be used to stir up popular anger. Recommending the production of special textbooks for this purpose, he stressed how important it

\footnotetext{
${ }^{42}$ Christopher R. Hughes, "Japan in the Politics of Chinese Leadership Legitimacy: Recent Developments in Historical Perspective," Japan Forum 20, no. 2 (July 2008): 245-66, doi:10.1080/09555800802047517, 247.

${ }^{43}$ Ibid., 253.
} 
was to draw attention to negative examples of people who collaborated with foreign powers or worshipped foreign things and lacked all trace of 'nationalist fibre.' Teaching materials for schools were peppered with stories of heroic child resistance fighters alongside images of CCP leaders and emblems and representations of the establishment of the Party, the PLA (People's Liberation Army) and the PRC. ${ }^{44}$

In striking this balance, China's New Nationalism encouraged frequent rehashing of past foreign aggression as a way marshaling domestic legitimacy. Individual factions also vied to outmaneuver competitors by polishing their nationalist credentials, leading to a brinksman-like competition of foreign provocation. The Senkaku/Diaoyu island dispute proved a durable, recurrent opportunity to establish those credentials. However, as the Senkaku dispute involved both Hong Kong and Taiwan, popular demonstrations of nationalism also constrained Chinese decision-making. In the face of a more rigorous claim to defending Chinese national sovereignty, the Communist Government risked losing out much as the Guomintang did by being seen as soft on foreign encroachment. ${ }^{45}$ Hughes describes the combined factors which lead China toward being constrained into belligerent statements and actions, and offer political capital to internal factions willing to one-up other belligerents.

\section{Economics}

Many observers link security arrangements in East Asia to trade relationships in the region. These economy-centered analyses fall into two broad camps: liberal observers predict a decrease in tension between China and Japan as their trade ties deepen. Realists predict a rising level of tension, as China gains builds its economic advantage into the military might that Japan constitutionally and culturally rebuffs. In the important

\footnotetext{
${ }^{44}$ Ibid., 248.

${ }^{45}$ Ibid., 254.
} 
Senkaku/Diaoyu dispute and Sino-Japanese political-economic relations, Min Gyo Koo describes the exponentially expanding trade between China and Japan as a source of cooperation. Min argues that while the two nations suffer from extreme historic antipathy, exacerbated by domestic political forces on both sides, trade ensures that the conflict will remain largely nonviolent. ${ }^{46}$

This argument is substantively repeated by political theorists who use China as a case study. Quddus Snyder describes China as a nation midway through the process of norm socialization. With deviations in line with other emerging economic powers (such as the United States in the early 1900s), China is viewed as on track to substantial trade linkages with the world. This liberal view of economics as a peace-keeper would place China in a position of enforced cooperation and non-belligerence with its important trading neighbors. ${ }^{47}$

This view is reinforced by the inclusion of trade data on foreign direct investment (FDI) in the literature: with surging FDI, the relative weight of economic matters in national decision making is presumed to increase, with a special focus on remaining in the good graces of foreign investors. ${ }^{48}$

Additional authors follow this pattern of analysis, citing economic integration as a strong moderating force on the contentious Sino-Japanese relationship. Shiro Armstrong describes Chinese membership in the WTO and earlier confidence-building reforms as a

\footnotetext{
${ }^{46}$ Min Gyo Koo, "The Senkaku/Diaoyu Dispute and Sino-Japanese Political-Economic Relations: Cold Politics and Hot Economics?," Pacific Review 22, no. 2 (May 2009): 205-32, doi:10.1080/09512740902815342, 228.

${ }^{47}$ Qz Snyder, "The Illiberal Trading State: Liberal Systemic Theory and the Mechanism of Socialization," JOURNAL OF PEACE RESEARCH 50, no. 1 (January 2013): 33-45, 43.

${ }^{48}$ Romain Wacziarg and Karen Horn Welch, Trade Liberalization and Growth]: New Evidence. NBER Working Paper Series: No. 10152 (Cambridge, MA: National Bureau of Economic Research, 2003), 209.
} 
foundation for regional trade. With these economic reforms in place, Japanese business interests have flooded China with FDI and market goods, which have led to a rapidly growing China and a modest Japanese economic recovery. ${ }^{49}$ Armstrong sees these improving trade ties as largely insulated from political conflict, as demonstrated through analysis of economic trends during periods of high political tension. The author furthers his point by citing the general trend toward improved relations between China and Japan since 2001, presumably in comparison to historic lows in the post-war period.

There is by no means a consensus on the effect of increased economic integration between nations which do not share a political system. Many analyses focus on the democracy dividend, or the hypothesized tendency of democratic states and trading partners to avoid war with one another. As China is not a liberal democracy, it may behave in a very different way to similar stimuli. The Naval War College Review's analysis of the Senkaku crisis focuses on the intensifying tensions amidst increased economic cooperation. Paul J. Smith argues that increased economic integration benefits the ascendant and revanchist China. The following quote sums up the argument neatly:

First, the power relationship between Japan and the People's Republic of China, which drives the dynamics of this dispute, is shifting. In the 1970s and, especially, the 1980s Japan's economic power was unrivaled in East Asia, while China was comparatively undeveloped and militarily weak. Today the situation has changed; the countries find themselves in an uneasy balance of relative military and economic parity. However, current trends appear to favor China. Japan, while the world's third-largest economy, is undergoing a gradual relative decline- economically, demographically, and ultimately militarily. Thus, underlying the bilateral tension over the Senkakus/Diaoyus is a palpable sense of power transition. ${ }^{50}$

\footnotetext{
49 Shiro P. Armstrong, "The Politics of Japan-China Trade and the Role of the World Trade System," World Economy 35, no. 9 (September 2012): 1102-20, doi:10.1111/j.1467-9701.2012.01473.x, 1117.

${ }^{50}$ Paul J. Smith, “A Crisis Postponed," Naval War College Review 66, no. 2 (Spring 2013): 27-44, 38.
} 
This argument is also backed, in broad strokes, by recent statistical research. In Mansfield, Milner, and Rosendorff's recent analysis, linkages are established between belligerent behavior and trade between 1960 and 1990, a core time period for this project. While trading partners are demonstrated to engage in warfare at a lower rate, the authors acknowledge a strong tendency for nations to pair off systematically: illiberal states pair with illiberal states, and vice versa. ${ }^{51}$ As a result, the predictive capacity of the model is limited by fewer data points amongst dyads such as modern Japan and China. The rarity of hybrid pairs and the relative paucity of trade between them suggest troublesome issues and scarce precedents for a potential trade-based relationship between countries of a dissimilar political background.

In short, the existing literature on the Senkaku dispute is as diverse as it is inconclusive. Central to existing analyses of the conflict, economics have a disputed role in the creation of a more cooperative relationship between China and Japan. Establishing a sound argument for the directional relationship between economic growth and security cooperation will be key for this report. Particularly in light of non-intuitive political pressures, like Fravel's example of international cooperation amidst domestic security crackdowns, political systems demand further scrutiny. The Chinese political system will require in-depth investigation, as general theories and patterns of Western European interaction do not appear to hold for the PRC. As multiple sources point to nationalism being a fostered resource in the PRC, we will eventually consider unforeseen externalities of stoking popular nationalism. First, though, we will discuss the escalating history of the Senkaku/Diaoyu dispute, to provide a context for our in-depth thematic discussions.

${ }^{51}$ Mansfield, Milner, and Rosendorff, "Free to Trade," 317. 


\section{CHAPTER IV HISTORICAL CONTEXT}

This study first considers the competing claims of territory and sovereignty of the Senkaku Island chain. As an uninhabited and inhospitable series of islets, the Senkakus have been inconsequential for most of their history. A small Japanese fish processing plant was established on the main island, Uotsuri Jima, in the early 1900s. By 1940, that business had failed, leaving the chain uninhabited and obscure other than for purposes of navigation on the East China Sea. ${ }^{52}$

\section{Sino-Japanese War}

In international relations, the islands also enjoyed relative obscurity until the discovery of energy resources after World War II. As a result of the Sino-Japanese War, China was forced to assent in 1895 to the Treaty of Shimonoseki, one of many Unequal Treaties signed by the late Qing Dynasty which ceded territory to foreign powers. ${ }^{53}$ This paved the way for Japanese industrialization of the isles around 1900, where the islands

\footnotetext{
${ }^{52}$ Eric Posner, "Why Are China and Japan Inching Toward War Over Five Tiny Islands?," Slate, February 25, 2014, http://www.slate.com/articles/news_and_politics/view_from_chicago/2014/02/the_senkaku_or_diaoyu_ islands_where_world_war_iii_could_start_because_of.html.

${ }^{53}$ Koo, "The Senkaku/Diaoyu Dispute and Sino-Japanese Political-Economic Relations," 207.
} 
were licensed for development to a private owner, which established the status quo that continued after the surrender of Imperial Japan in 1945. The original private owners sold their title to the Kurihara family, whose descendants would ultimately sell their stake to the Japanese central government in 2012. ${ }^{54}$

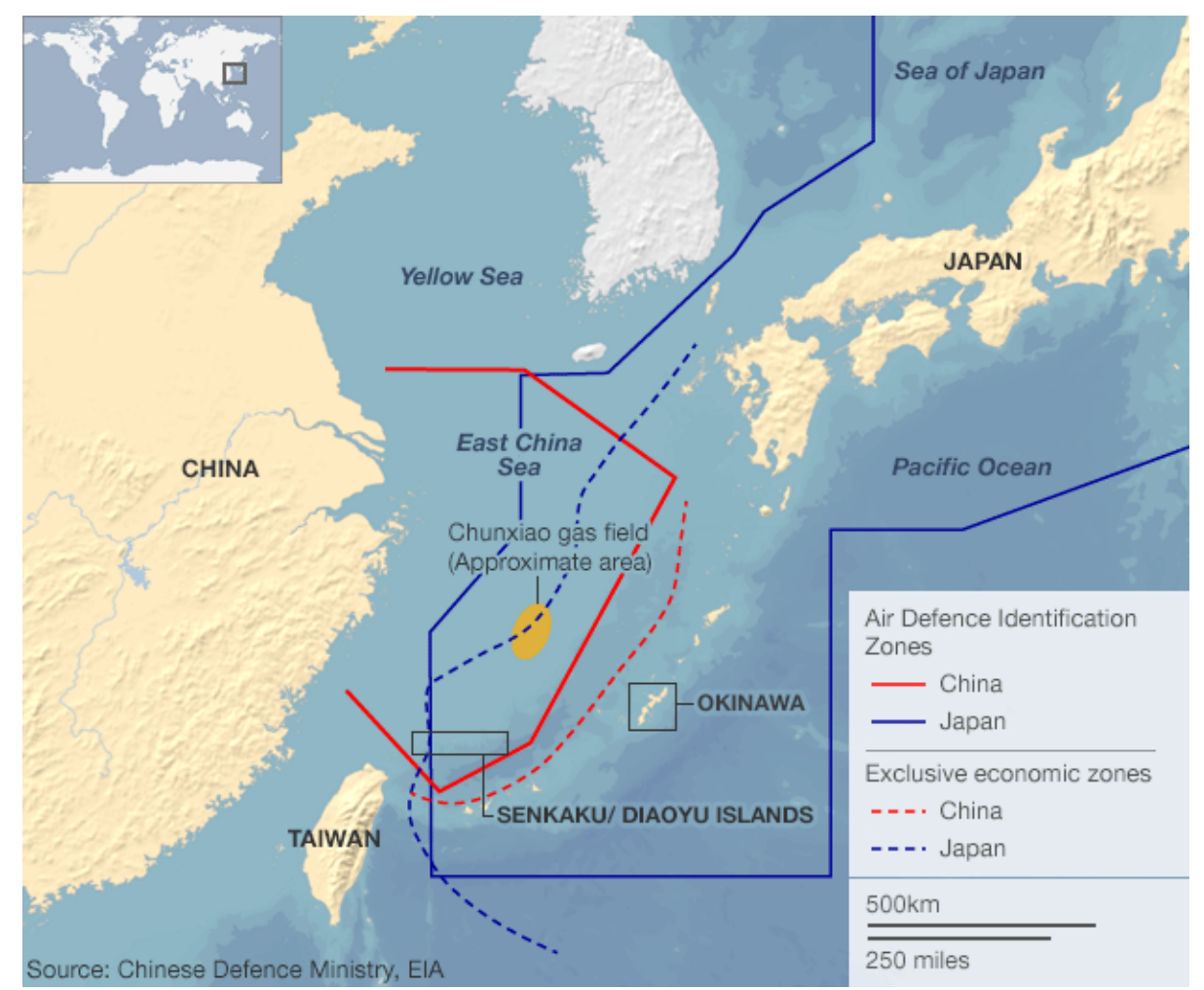

Figure 1. Map of East China Sea. ${ }^{55}$

Disagreements over the fate of the islets grew out of a rapid-fire string of events following the American reversion of Okinawa to Japan in 1970. Contemporaneously, oil and natural gas prospectors discovered ample resources in the disputed zone between China, Taiwan, Korea, and Japan. The discovery focused on the continental shelf, where

\footnotetext{
54 "Who Really Owns the Senkaku Islands?," The Economist, December 3, 2013, http://www.economist.com/blogs/economist-explains/2013/12/economist-explains-1.

55 "China Sends Warplanes to Air Zone," BBC News, accessed July 24, 2014, http://www.bbc.com/news/world-asia-china-25144465.
} 
oil developments are technically and economically advantageous. See Figure 1 for a geographic illustration of the Chunxiao Gas Field with respect to the Senkaku islands. The extent of the development was underlined by the United Nations team responsible for the find:

A geological survey, conducted by the Committee for Coordination of Joint Prospecting for Mineral Resources in Asian Offshore Areas (CCOP) under the auspices of the United Nations Economic Commission for Asia and the Far East (UNECAFE), suggested that 'a high probability exists that the continental shelf between Taiwan and Japan may be one of the most prolific oil reservoirs in the world, with potential estimated at between 10 to 100 billion barrels, ${ }^{56}$

With this discovery, a flurry of activity surrounded the islets as nations vied to use them as an anchor to enhance oceanic territorial claims. The mainland Chinese lodged complaints with the United States, followed by bitter recriminations over the repatriation of Okinawa. As Okinawa is part of the same island chain, the Ryukyus, the Senkaku islands were drawn into the debate. Japan and the United States struck a conciliatory tone, delaying the repatriation of the whole series of islands for a year and avoiding unilateral oil development in the region. ${ }^{57}$ This highlights the role of the United States as an officially neutral arbiter of the dispute, although as is evident in ubiquitous official media pronouncements, the United States is increasingly seen by the Chinese Communist Party as an ally of the Japanese.

\section{The Fishing Expedition}

The dispute was shelved as part of a strategy by the Japanese and Chinese to use economic development as a common cause to avoid conflict. It did not remain out of the limelight for long: the issue resurfaced in 1978 in a series of events known as The Fishing

\footnotetext{
${ }^{56}$ Koo, "The Senkaku/Diaoyu Dispute and Sino-Japanese Political-Economic Relations," 213.

57 Ibid., 210.
} 
Expedition. To fully understand this flare-up of the history of the Senkaku Islets, the observer must consider the radical changes occurring in the regional balance of power at the time.

The People's Republic of China and Japan had a long and tenuous road to normalized political relations after the Second World War. In particular, the Chinese Communist Party resisted efforts to integrate into the wider international political order. The first step to more regular interaction was the Joint Communique of the Government of Japan and the Government of the People's Republic of China in 1972, which was followed by the Peace and Friendship Treaty of 1978. The Joint Communiqué took the nations out of their estranged state, while the PFT sought to resolve difficult issues preventing further economic integration and Soviet deterrence. ${ }^{58}$

The Peace and Friendship Treaty held alternate promises for the two negotiating parties. For the Chinese, the "anti-hegemony clause" was the most important concession, creating a unified front between Japan and the PRC in the event of hostilities with the Soviet Union. This diplomatic focus highlights the sometimes-neglected conflict and paranoia surrounding China's relationship with the Soviets. The Japanese negotiators, and in particular the conservative wing of the singular Liberal Democratic Party, resisted the possibility of political alliance with the Chinese. For their part, the Japanese negotiators saw the PFT as an avenue for decreased animosity and increased trade. ${ }^{59}$ In particular, the Keidanren, or Federation of Economic Organizations, encouraged the Japanese government to negotiate for greater trade ties: the Chinese mainland held the

\footnotetext{
58 "MOFA: Joint Communique of the Government of Japan and the Government of the People's Republic of China," accessed July 24, 2014, http://www.mofa.go.jp/region/asia-paci/china/joint72.html.

${ }^{59}$ Chae-Jin Lee, "The Making of the Sino-Japanese Peace and Friendship Treaty," Pacific Affairs, 1979, 426.
} 
energy resources that had long constrained Japan's economic growth, as well as the eventual promise of a massive market for the industrial goods Japan produced. ${ }^{60}$

As a poison pill, negotiators from the conservative faction of the LDP attempted to water down the anti-hegemony clause. Both sides took a keen interest in the exact phrasing of the treaty, with Japanese negotiators opting for a less enforceable document. ${ }^{61}$ Profoundly sensitive, the issue effectively stalled negotiations. This was a subtle and peaceful rebuke, which characterizes conservative Japanese resistance over cooperation on the island issue. As the negotiations foundered, a contiguous series of events unfolded, assisting in the creation of another sovereignty flare-up.

In 1976, Mao Zedong died of natural causes in the Zhongnanhai Party Compound in Beijing. This touched off a series of tumultuous power-grabs among the Communist Party's ruling cliques, as no formal structure existed for peaceful power transition. A brutal sequence of coups and countercoups isolated and destroyed the obvious heir apparent of Mao's rule. ${ }^{62}$ The leftist faction, inheritors of Mao's doctrine of mass mobilization and "continuous revolution," were led by the fractious Gang of Four, including Mao's surviving wife Jiang Qing. The conservative faction within the Chinese Communist Party, bolstered by the disaster of the Great Leap Forward and surviving the subsequent violent purges of the Cultural Revolution, opposed the doctrine of continuing tumult. The conservatives won out in a series of power plays, led by Deng Xiaoping and Hua Guofeng, while their position was enhanced by the increasingly undeniable signs of

\footnotetext{
60 Ibid., 428.

61 Ibid., 441.

62 J. a. G. Roberts, A History of China, Palgrave Essential Histories (Houndmills, Basingstoke, Hampshire?; New York City, NY?: Palgrave Macmillan, 2011). $3^{\text {rd }}$ edition, 288.
} 
massive famine in the countryside as a result of governmental neglect and intentional denial of support. ${ }^{63}$

The resulting international arena was fraught with peril for the prospects of delicate negotiations. Illustrating the balance between internal hegemony and external aggression in mainland China, Deng Xiaoping ordered a fleet of more than 100 fishing trawlers to siege the Senkaku Islets whilst draped in oversized Chinese national flags. The resulting diplomatic firestorm affirmatively sank the stalled negotiations over the islets. The series of events shows that Deng Xiaoping, as with future Chinese leaders, uses unilateral aggressive actions to neutralize resistance to party hegemony within the Chinese mainland. The demonstration was followed by a rare display of Japanese parliamentary consensus to denounce China. Further, Japanese ultranationalist groups sailed for the islands to establish a lighthouse, which would become a recurring flashpoint for international escalation over the islands.

After months of crisis, the dispute was again shelved by mutual agreement between China and Japan. Japanese Prime Minister Fukuda Takeo announced that his government was returning to the PFT negotiating table after abruptly departing the process at the start of the crisis. Deng Xiaoping, after an extended period of nationalist fervor allowed him to consolidate power, removed the Chinese fleet from the disputed waters. By using People's Liberation Army Navy commanders on the involved fishing trawlers, China brought a dangerous military element to the gamesmanship around the

\footnotetext{
${ }^{63}$ Jisheng Yang et al., Tombstone?: The Great Chinese Famine, 1958-1962 / Yang Jisheng?; Translated from the Chinese by Stacy Mosher and Guo Jian国; Edited by Edward Friedman, Guo Jian, and Stacy Mosher?; Introduction by Edward Friedman and Roderick MacFarquhar (New York City, NY: Farrar, Straus and Giroux, 2013), 429.
} 
islets. ${ }^{64}$ The fact that the fishing trawlers were armed with heavy weapons, ostensibly to prevent the Japanese coast guard from interfering, also raised the level of risk. ${ }^{65}$ Notably, Japan considered and perennially rejected using military vessels to protect its islet administration, weighing de-escalation and remaining militarily unprovocative as more important than the risk to their claimed territorial sovereignty.

The so-called fishing expedition and the Peace and Friendship Treaty from which it stemmed offer an early example of the two nations' conflict management styles. There is uncertainty over the official nature of the fishermen's protest, since during the final, successful phase of treaty negotiations Deng Xiaoping claimed that the fishermen had only swayed off course by accident. ${ }^{66}$ Whether or not this denial is credible or just a means of saving face, there is no uncertainty about Chinese policy after the protest began. The Chinese Communist Party denounced Japanese diplomatic overtures for intervention, citing unilateral ownership of the islets. This highly aggressive, diplomatically irregular negotiating style serves two purposes: the first is that it allows the Chinese to probe the solidity of Japanese negotiating positions. The second is that it allows the ruling clique to invoke an intense foreign entanglement as cover to subdue domestic opposition.

\section{The First Lighthouse Incident}

The issue was again raised, this time under the initiative of Japanese citizens in nationalist groups, in a series of events known as the Lighthouse Incident. The previous establishment of a lighthouse in the late 1970s was followed up by similar ultranationalist

\footnotetext{
${ }^{64}$ Koo, "The Senkaku/Diaoyu Dispute and Sino-Japanese Political-Economic Relations," 218.

${ }^{65}$ Lee, "The Making of the Sino-Japanese Peace and Friendship Treaty," 430.

${ }^{66}$ James Manicom, Bridging Troubled Waters]: China, Japan, and Maritime Order in the East China Sea. (Washington, DC?]: Georgetown University Press, 2014), 45.
} 
advocacy groups returning to refurbish the structure. After building the edifice to Japanese Maritime Safety Agency (JMSA) standards, the ultranationalists applied for a permit for the lighthouse to be recognized as a navigation aid in 1989. The government did not oppose the move in the early stages, which cast the die for a renewed struggle.

Initially, the Chinese response was restrained: complex international maneuvering was required to limit sanctions after the Tiananmen Square massacre, in which unarmed protestors were fired on after the declaration of martial law. While the Chinese government actively obstructs inquiries into the total number of its citizens who were killed, the official tally stands at 218 civilians. Sources outside the Chinese Communist Party estimate several thousand civilian deaths in the capital, excluding extrajudicial killings after the event and deaths due to the denial of medical treatment. ${ }^{67}$

Ultimately, the issue of the lighthouse was resolved as the Japanese and Chinese government colluded to shelve the conflict. Japan denied the ultranationalists' application for recognition of the lighthouse, and the Chinese did not press. Complex internal power dynamics limited the Chinese government's freedom of maneuver- reformers faced the dual strain of a nascent and faltering liberal economy alongside internal strife. There is a very real possibility that the Communist Party tempered its reaction to allow trade ties with Japan to mature.

\section{The Second Lighthouse Incident}

Tumultuous economic reforms in China paired with an aggressive foreign posture ensured that the Senkaku Islets were not uncontested for long. In 1996, the Japanese

\footnotetext{
67 "The Memory Of Tiananmen | The Tank Man | FRONTLINE | PBS," accessed July 24, 2014, http://www.pbs.org/wgbh/pages/frontline/tankman/cron/.
} 
ultranationalists returned to Uotsuri to refurbish their lighthouse. The political climate was exceedingly tense, which led to the resulting flareup being more severe. Chinese military forces accelerated underground nuclear testing, leading to protests from the Japanese Diet. ${ }^{68}$ Further, the Taiwan Straits Crisis of 1995-6 primed the region for further destabilizing conflict. In response to provocative Chinese military exercises, including the "testing" of missiles 30 miles off the Taiwanese coast, an American carrier group was sortied to the Taiwan Straits.

In this environment of severely strained relations, the Second Lighthouse Incident proceeded in earnest. Seven Japanese activists raised the old ultranationalist lighthouse, and once again requested government sanction, which was denied. Chinese activist David Chan, who sailed as part of the Baodiao, or Protect the Diaoyu Movement from Hong Kong, died in the waters off Senkaku in an altercation with the Japanese Maritime Safety Agency. While his death was apparently an accident that resulted from rough seas during his swim to shore, public opinion was enflamed in mainland China, as well as in Taiwan and expatriate communities in the United States. The recovery of the activist's body by the Japanese coast guard was treated with suspicion and hostility in the activist community. As a result, further activist flotillas sortied from China and Taiwan, successfully planting various national flags on the Senkaku islets.

The especially fraught environment was recognized by the two principal actors, Japan and China, who both sought de-escalation. Japanese government officials were restrained in their response to routine disruptions by Baodiao activists. The application

\footnotetext{
68 "CNS - China's Nuclear Tests," accessed July 24, 2014, http://cns.miis.edu/archive/country_china/coxrep/testlist.htm.
} 
for lighthouse recognition was once again denied, although that did little to allay accusations of ultranationalist sympathies leveled against the Japanese government. The Chinese Communist Party was alarmed at the strength and furor of nationalist sentiments on the mainland aroused by the death of David Chan. It quickly denounced him, suppressed news of his death, and sought to marginalize the nascent activist base growing within its borders and in expatriate communities abroad. ${ }^{69}$ This reinforces the tendency of the Chinese government to consider internal hegemony paramount, even at the expense of international claims.

\section{Flare-up and the Race for Natural Resources}

Highlighting the explosive underpinnings of conflict over the Senkakus since 1972, the next international incident focused on the islets directly acknowledges the struggle over natural gas and oil exploration. At the core of the issue from inception, neither party concerned can back away from possession of the islets which would bolster mineral claims. Japan in particular suffers from resource scarcity, backstopping its uncompromising position on the islets. The Chinese government, for its part, views the petrochemical industry as both a source of growth in itself as well as a strategic resource which underpins all industrial development.

In an ongoing trend, Chinese activists were arrested by Japanese JMSA officials for violating Japanese law after planting their national flags on the Senkakus in 2004. The routine request for remediation by the Japanese was rebutted by the mainland Chinese, who countered with strong condemnation of the detention of Chinese citizens. This

\footnotetext{
${ }^{69}$ Koo, "The Senkaku/Diaoyu Dispute and Sino-Japanese Political-Economic Relations," 225.
} 
follows the general pattern of the PRC government repudiating of regular diplomatic activity during times of crisis. The aftermath illustrates the slowly increasing autonomy of the Chinese public, given the rise of microblogging and mobile communication technology in China. This trend of independent organization and civic communication is a source of deep discomfort for the leadership clique in the Chinese Communist Party. Anti-Japanese protests followed in major Chinese cities, resulting in damage to the Japanese embassy in Beijing as well as various Japanese investments in the country. The violence was indiscriminant, down to the targeting of hapless drivers of Japanese-branded automobiles manufactured in China.

This political conflict was undergirded by simultaneous resource exploration near the disputed territories. Chinese resource exploration vessels triggered alerts within the JMSA, prompting a formal complaint by the Japanese government. These diplomatic entreaties failed, and China began developing natural gas extraction rigs in 2004. The Japanese responded in kind, with both parties violating earlier agreements to delay resource extraction until a settlement is reached.

As with the Lighthouse Incidents, a conflux of factors exacerbated the crisis. Rapid developments on the islets involved the JMSA taking official ownership of the ultranationalist lighthouse. A traditional trigger for mainland protests, the lighthouse issue again ignited Chinese nationalism, with an uncommonly violent string of protests. In official diplomatic channels, the Chinese rebuffed demands for apology and compensation over damages inflicted during the riots. As a counterpoint, the Chinese attributed the unrest to unsatisfactory Japanese apologies over past war crimes. This 
illustrates the unique, Chinese brand of diplomacy, with difficult-to-predict interludes of ordinary cooperation mixed with strident refutation of diplomatic norms.

To resolve the crisis, the two countries again sidestepped the central conflict. To answer the call for wartime apologies, Japan agreed to a bilateral study of the Chinese and Japanese history. This de-escalated the train of events that had so recently provoked violent outbursts on the mainland. In the East China Sea, the negotiations were more fraught. After multiple rounds of deal-making were hindered by sovereignty disputes, the two countries agreed to joint development at 4 natural gas sites in the region. ${ }^{70}$ Even this incremental development would eventually be undone by renewed conflict over the islets. $^{71}$

\section{Flare-up and the Nationalization Crisis}

The increased economic ties between China and Japan have had limited success in preventing the two regional powers from tense standoffs. Recent events riff on familiar motifs in the conflict, but with China increasingly able to project force for a possible violent challenge to the status quo. The most recent Senkaku controversy stems from a string of events, once again, fomented by Japanese nationalist groups. Led by the conservative Mayor of Tokyo prefecture, Ishihara Shintaro, a national fundraising drive sought to purchase the Senkaku Islets privately from their Japanese owner. The central government pre-empted the move, nationalizing the islands to prevent further gamesmanship by the nationalists. The die, however, was cast. The move predictably infuriated the mainland Chinese.

\footnotetext{
${ }^{70}$ Smith, "A Crisis Postponed," 38.

71 "Japan Complains over China Drill Rig," BBC News, accessed July 24, 2014, http://www.bbc.com/news/world-asia-23159436.
} 
In a now-familiar milieu, 85 Chinese cities experienced major anti-Japanese protests. Thousands of marchers took to the street in a two-week stretch, sometimes using violence to underscore their displeasure. Both governments closely monitored the treatment of Japanese citizens and property in China, although the Chinese government did little to protect the latter. Concurrently, the People's Liberation Navy sailed a group of 7 warships through the Miyaku Strait, which separates Okinawa from the southernmost home island of Honshu. China filed no advanced notice with Japan for these maneuvers, repudiating a security agreement in what is widely believed to be a protest over the Senkaku Islets. ${ }^{72}$

In this uncertain security environment, the United States has transitioned away from its longstanding neutrality on the Senkaku question. After four decades of delicate fence-sitting, Secretary of State Hillary Clinton confirmed in October 2010 that the Senkaku Islands would be considered Japanese territory for the purposes of mutual defense pacts. ${ }^{73}$ While this leaves the political and economic conflict in question, it does much to rebalance the possible gains to precipitous military action in the region. This confirmation follows a long period of official neutrality, apparently as a salve to SinoAmerican relations, although the chilled atmosphere demonstrates that such small concessions were insufficient to shape Chinese government views.

In recent events, the unilateral establishment of a Chinese air defense zone over the islets has further exacerbated tensions. Following on the heels of numerous reports of Chinese military aircraft patrolling overhead, this may be the new pattern for the Senkaku

\footnotetext{
${ }_{72}^{72}$ Smith, “A Crisis Postponed," 39.

${ }^{73}$ Ibid., 40.
} 
dispute. The inclusion of military forces invites a potentially disastrous new avenue of possibilities, given the Chinese military's penchant for gamesmanship, such as the targeting of fire-control radars on American and Japanese naval vessels. ${ }^{74}$ While the Japanese and American forces can repudiate unilateral aerial cordons by violating them, this risks confrontation with a newly emboldened and rearmed China. Given the pattern of escalation in the Senkaku dispute, it behooves policy-makers to understand what factors drive ongoing conflict. Hopefully, the multilayered and tangled narrative of the dispute up to this point has served as a demonstration of the issue's complexity. To better understand that complexity, we will consider factors beyond the conflict which explain its nature and longevity.

\footnotetext{
74 “Japan PM Condemns China Radar Act," BBC News, accessed July 24, 2014, http://www.bbc.com/news/world-asia-21347915.
} 


\section{CHAPTER V ECONOMIC CONTEXT}

The global economy has experienced radical shifts since World War II. As globalization pervades the marketplace, industries formerly dominated by the Western industrial states have opened up. This transformation is critical to understanding the power dynamics of East Asia, which is at the center of global economic rebalancing. For this study, we will first consider Japan, an archetype for explosive growth that now sits in the fraternity of industrialized nations. The desolation of Japan and much of East Asia during World War II provided a largely blank slate for economic growth, and this human development does much to provide context for the current tension in the region. We will then consider Communist China, a late-comer whose meteoric rise is still being counterbalanced by the global and regional economy. China, a nation with few of the intrinsic size and resource limitations of the Japanese home islands, has charted an impressive course of growth through hybrid communist/market policies. Lastly, we will view trade ties between the two powers and their relationship over energy resources as a case study for how economic growth and competition effects international cooperation.

Japan: Industry from Ashes

Japanese re-industrialization after the war was perhaps the first economic upset stemming from globalization in the post-war period. The widely held assumption that 
non-western nations would not compete industrially was challenged through a series of successful policies enacted during the American ${ }^{75}$ occupation and subsequent Japanese administrations. Not widely recognized, this pattern of explosive industrial growth has precedents in Japan's interwar years. During the interwar years, also referred to as the Meiji Restoration, Japan's industrial output increased by 600 percent. Compare that to the relatively more advanced but not yet fully developed American market which increased by only 66 percent. ${ }^{76}$ This was the result, on the one hand, of effective industrial policies and a stability-focused government. It was also the result of mercantile conquest, as the Korean peninsula was aggressively colonized for access to cheap labor and raw materials. A similar process was undertaken in northern Chinese provinces, with a similar level of brutality, to the lasting displeasure of both the Chinese and Korean governments.

Immediately after World War II, Japan was physically ruined. The institutions and human capital that had created the pre-war prosperity, however, were still largely in place. The United States, after initial indecision on the matter with fears over war industries, firmly backed Japanese industrial growth. This took the form of a relatively benevolent occupation, focused on economic and institutional development rather than war reparations. Accordingly, during the Korean War, Japan benefitted greatly from its preferred status in filling wartime supply contracts. Most importantly, these policies involved the opening of American markets to Japanese goods. The political drives toward this American policy are succinctly described by Chalmers Johnson, an expert on the Japanese economy:

\footnotetext{
${ }^{75}$ While nominally a multinational coalition, the office of the Supreme Commander of Allied Powers (SCAP) was dominated by Americans during the occupation. This is a sharp contrast to the joint occupation of Germany, divided into zones which would eventually become formal boundaries. ${ }^{76}$ Mikiso Hane, Eastern Phoenix?: Japan since 1945 (Boulder, CO: Westview Press, 1996), 108.
} 
The American approach to Japan after the war was to declare that Japan was of great strategic importance and very little economic importance. It was for this reason that we allowed Japan to maintain protection of its domestic markets much longer than any European country, to maintain an undervalued currency much longer, why we transferred huge amounts of technology to Japan at bargain basement prices, and also gave Japan virtually unlimited access to the world's largest market, namely the American market... ${ }^{77}$

As a result of strategic considerations stemming from the Cold War, Japan gained access to practically bottomless export market and a reliable source of raw materials. This enabled the Japanese government and corporate concerns to pursue a classic pattern of industrial development, focusing first on low-skill manufactures (principally textiles), and then leveraging that success into high-skill manufactures (such as automobiles and electronics). This process was eased by American sponsorship of the Japanese request in 1955 to join the General Agreement on Trade and Tariffs (GATT), an early predecessor of the World Trade Organization (WTO), which was accepted in 1963. Consider that the Chinese process to join the formal international trading community was much less successful, with their GATT application being derailed by human rights violations during the Tiananmen Square Massacre in 1989.

Several unique characteristics of the Japanese economy aided its successful transformation. In a nation where policy development is characterized by intensive bureaucratic involvement, the Ministry of International Trade and Industry (MITI) stands among the most powerful bureaucracies. The MITI encouraged wholesale importation of manufacturing technology, largely on favorable terms from the United States. Certain reforms sponsored by the Americans, such as the occupation-era anti-monopoly statutes,

\footnotetext{
${ }^{77}$ Ibid., 108.
} 
were repealed during the postwar boom. This conglomeration aided in the eventual shift toward heavy industries, as components and finished products could be manufactured within one self-sufficient supply chain.

The Japanese economy re-centered itself around several massive, diversified conglomerates. The structure of these keiretsu, or business communities, forces costly expenditures onto the smaller subsidiary companies while maintaining the growth of the vast parent company. This structure was particularly advantageous for the automobile industry, which serves as a useful example of Japan's export boom. With a tradition of heavy manufactures in shipbuilding and military hardware, Japanese industry was well poised to take over export automobile market shares in a way other emerging economies were not. Strict limitations of capital movement allowed for Japanese companies to reestablish themselves with limited foreign investment, and thus profits were available for domestic reinvestment. Similarly, an intricate network of regulations prevented the easy importation of foreign manufactures to Japan. For example, each imported automobile must be manually inspected for defects by customs officers upon arrival. ${ }^{78}$

As such, while the Japanese economy grew, that was a centralized process, one which depended on access to foreign markets more than access to foreign investment. In the early postwar period, Japan benefitted greatly from a lack of regional competitor, as China was mired in revolutionary violence. This pattern could not last forever, which Japanese policy recognized in the form of aid to a former military opponent and probable future economic competitor.

\footnotetext{
${ }^{78}$ Ibid., 80.
} 


\section{China: Newcomer and Giant}

China followed a very different developmental trajectory after World War II. Where Japan was fostered by the United States as a bulwark against communism, China resided on the other side of the Iron Curtain. The United States recognized the Nationalist government as the legitimate rulers of China after the Chinese Civil War, going so far as to hold the Taiwan Straits with the US Seventh Fleet to prevent forcible reunification. The Chinese Communist Party could not even rely on their nominal allies in the USSR, as deep distrust reigned in that tempestuous relationship. China, underdeveloped before the war, set about a policy of isolation and self-development that was marred by revolutionary disorganization. It was not until the collapse of the Soviet system that the People's Republic fully embraced market-based economic reforms, hastening industrial growth and eventually leading to membership in the WTO.

Following the revolutionary tumult of the Great Leap Forward and subsequent Cultural Revolution, China was faced with a conundrum. Economic development was sagging, while regional competitors were exhibiting unprecedented growth. Market reform was initiated in China in 1978, just as Japan was settling into a pattern of explosive growth. The USSR, while readying the military buildup which would eventually derail its economy and political system, presented a model for comparatively successful communist development. For comparison, at the earliest initiation of marketreform in China, the average Chinese citizen made 226 USD\$ annually. By contrast, the average Japanese citizen made 8,675 USD\$ annually, or roughly 38 times as much. ${ }^{79}$

\footnotetext{
${ }^{79}$ World Bank Data, “Japan | Data," accessed July 24, 2014, http://data.worldbank.org/country/japan.
} 
To address these deficiencies in the Chinese command economy, the CCP instituted a series of slow-moving reforms to test essentially market-based approaches in a hybrid system. ${ }^{80}$ The first of these was agricultural: a centerpiece of the revolutionary Chinese economy was the communal farm. The farms constituted the primary mode of organization for China's vast rural population. In a radical departure, the Chinese government relaxed their grain procurement quotas while increasing the price allotted for the compulsory sales to the government. Most importantly, the communes contracted out parcels of land to individual families, allowing surplus beyond the quota to be sold at market price. These policies allowed the practical disbanding of communal farms, while the organizations went on in name for several more years. Finance for the rebalanced grain prices was procured by limiting other programs, notably the "Great Leap Outward," which was an ambitious plan for industrial modernization through the purchase and importation of Western technology. ${ }^{81}$

Market-based incentives were integrated piecemeal into the Chinese system, coming to a head in the 1980s. After initial success in agriculture, commercial manufacturing was addressed in two waves. The first wave, indicative of Chinese policy making in general, was undertaken cautiously over a period of years. Under the premiership of Deng Xiaoping, party leader Zhao Ziyang embarked on a mission of nondisruptive reforms. Special care was taken to shield the workers in state-owned enterprises (SOE), which led the changes to be collectively known as reform without

\footnotetext{
${ }^{80}$ Barry Naughton, The Chinese Economy[: Transitions and Growth (Cambridge, MA.]?: MIT Press, 2007), 87. ${ }^{81}$ Ibid., 78.
} 
losers. ${ }^{82}$ Competition was injected into the moribund Chinese industrial economy through a series of reforms to encourage low-level industrial growth. Tax rates were negotiated with individual corporations with the goal of fostering new entrants under the particularistic contract system. This system of individually negotiated tax rates gave the government extraordinary control over industrial development.

The most important instrument used to usher in the second wave of market reforms was the shuangguizhi, or dual-track system. In the same model as earlier reforms to the communal farms, industries were given a command quota at a set price, typically below market value. They were then allowed to sell a surplus in excess of that quota at market price. The transformative effect this had on the Chinese economy cannot be overstated. Industrial production surged across a broad spectrum of markets, kicking off two decades of rapid economic growth for China. The shuanggui system was used to slowly transition the Chinese command economy to market incentives, picking up speed in the 1990s. For instance, the particularistic contracts which were used in early reforms were phased out over a number of years, replaced by a uniform tax code. The function of the old contract system had been replaced and streamlined by the new quota system, with a net benefit toward suffering government revenues. ${ }^{83}$ See Figure 2 for an illustration of the success of these reforms.

82 Ibid., 91.

${ }^{83}$ Ibid., 102. 


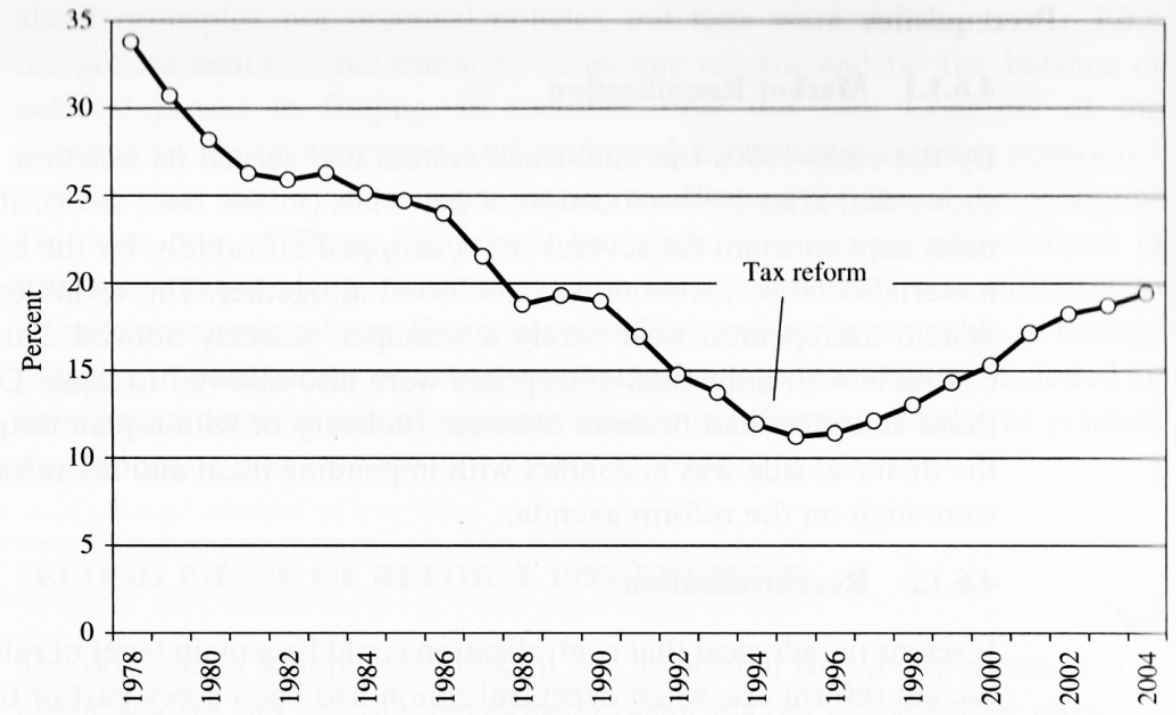

Budgetary revenue share of GDP

Figure 2. PRC Budgetary Revenue Responds to Reform. ${ }^{84}$

This is not to suggest that the dual-track system created a painless transition. The second wave of market reforms was characterized by substantial downsizing in SOE employment. Consider Figure 3 for SOE employment statistics over the course of the reforms. Public employment, known during the revolutionary period as "the iron ricebowl" due to its guarantee of a minimum standard of living, lost much of its social cache and stability. The second wave of reforms, administered by the charismatic Zhu Rongji, introduced privatization as a means of increasing market competition. The effect was twofold: first, the economy surged, fueled by newly confident international investors. Second, Chinese workers suffered from a greater degree of personal insecurity, with the social safety net lagging behind in filling the gaps. ${ }^{85}$ This suggests a weakness in the

\footnotetext{
${ }^{84}$ Ibid., 102.

${ }^{85}$ Note the break in official data during the sharp decline in SOE employment in the 1990s. This matches with the general PRC policy of not reporting data that may be considered embarrassing or dangerous to
} 
liberal interpretation of economic growth as a pacifying force: in China, spectacular macroeconomic growth coincides with increased personal insecurity due to pollution and inadequate social safeguards.

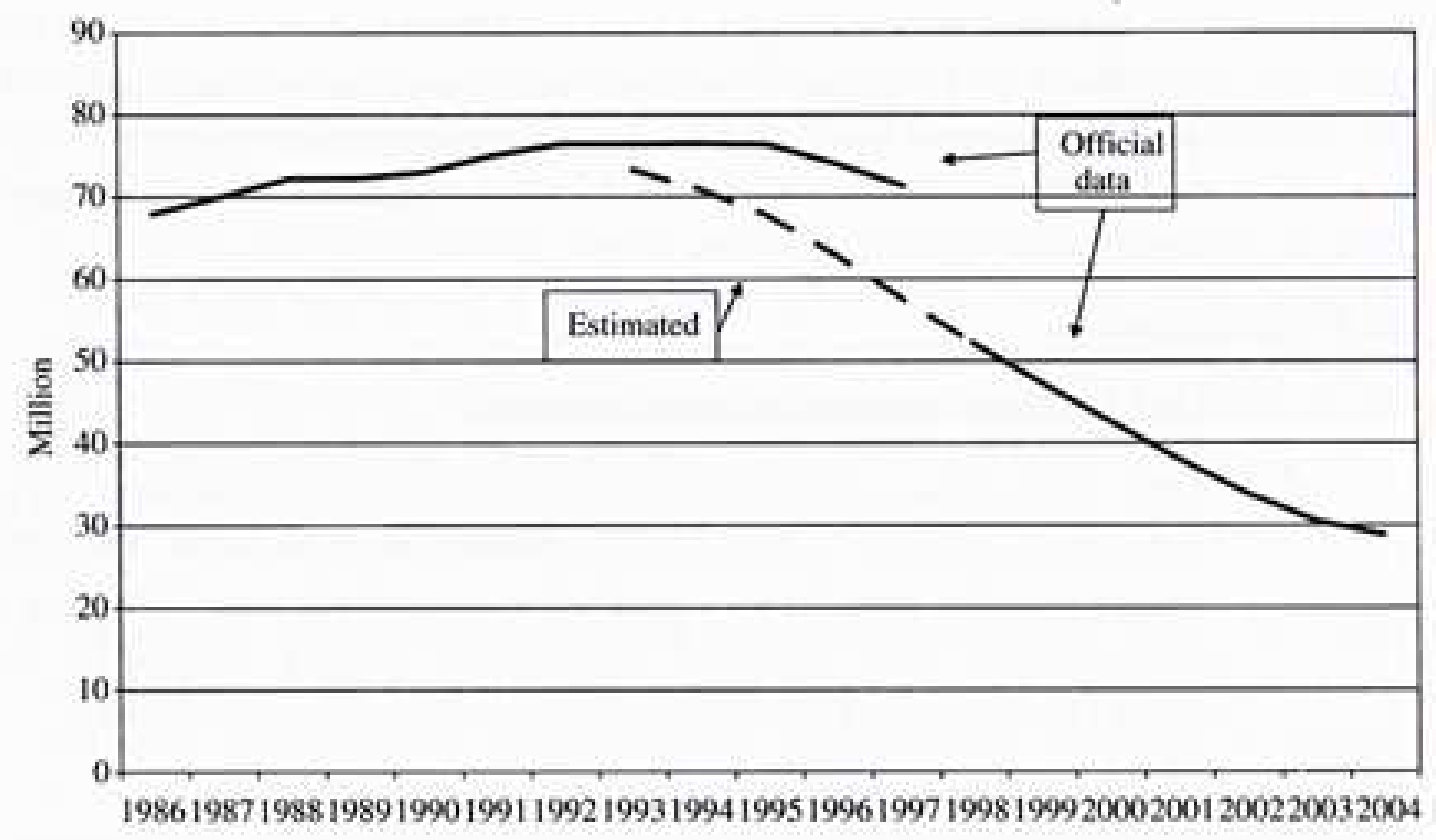

Figure 3. SOE Employment with Estimated Data. ${ }^{86}$

Of particular importance to Chinese decision making in international affairs,

China has become heavily reliant on foreign direct investment as a means of financing its development. This intervention is characterized in a number of ways. Compared to other developing nations, China's foreign investment is massive. FDI peaked at six percent of GDP in 1994, compared to one to two percent for periods of comparable economic

the Party. Bear this tendency in mind during the discussion of currently-unpublished internal security budgets.

${ }^{86}$ Ibid., 106. 
expansion in South Korea or Japan. ${ }^{87}$ Investment is disproportionately represented in the manufacturing sector, with a special focus on export manufacturing. For instance, 88 percent of China's high technology export firms are heavily foreign invested. ${ }^{88}$ This process was encouraged in a number of ways by Chinese government policy, of which special economic zones were a centerpiece.

Special economic zones (SEZs) were created, at first cautiously, to lure foreign manufacturing concerns to the mainland. The success of early zones, such as Shenzhen in Guangdong province, led to the rapid expansion of existing zones and the creation of new areas of free trade. The mechanisms of the SEZs essentially carved out an economically autonomous zone from the home country. Import and export duties on raw materials were waived. Administrative procedures were simplified, with a variety of permitting processes being handled through a single, central office. Taxes were administered in a preferential scheme, with a full tax holiday for a negotiated number of years, followed by a gradual introduction of the regular rate. ${ }^{89}$ This host of preferential conditions, combined with China's political stability compared to its developmental peers, proved to be a strong lure for foreign investment.

The format for SEZs again highlights the cautious nature of Chinese economic policymaking. In a system analogous to the shuangguizhi but applied to foreign investment, a dual-track system was created. The special zones were laboratories for experimental economic policies, segregated from the bulk of the Chinese economy. ${ }^{90}$ The

\footnotetext{
${ }^{87}$ Naughton, The Chinese Economy, 404.

${ }^{88}$ Ibid., 407.

${ }^{89}$ Ibid., 407.

${ }^{90}$ Ibid., 408.
} 
predecessor to the SEZ system, the export processing system, operated under a similar design. Foreign raw materials were transferred to Chinese factories, processed, and then returned to the foreign company for sale after a processing fee was paid. At no point were domestic markets or companies challenged. The SEZ system, with its export focus, provides a scaled-up version of this domestic market protection amid foreign trade engagement. The system allowed China to slowly introduce foreign competition, largely to meet conditions of World Trade Organization membership, after domestic industries had an opportunity to increase their competitiveness on foreign markets.

Encouraging direct foreign investments into China's manufacturing capabilities had multiple benefits for the economy. Technology development programs, initiated in the 1980s and recently covered in the international press for corruption, failed to provide China with the manufacturing capital to compete with foreign businesses. As such, an inviting program for FDI allowed foreign businesses to lend their manufacturing technologies directly to Chinese subsidiaries in the SEZs. The foreign importation of technology has vastly outstripped the Chinese domestic capacity to develop its own advancements since the market opening of $1993 .{ }^{91}$ This transfer of economic capital does not solely consist of machinery. Multinational corporations (MNCs) also invest in Chinese citizens' managerial capabilities, offering local employees exposure to efficient business practices. While the benefits of market investment are numerous for the Chinese economy, they also present a threat to the Communist Party leadership.

Central to Chinese economic planning is the idea of self-sufficiency. The Century of Humiliation, from the start of the Opium War in 1839 to the end of the Pacific War in

\footnotetext{
${ }^{91}$ Ibid., 406.
} 
1945, was characterized by foreign domination of the military and economic spheres of China. This historical legacy impacts the Chinese public and policymakers in a way that more recent, suppressed events cannot. While China's growth has been spectacular, it also raises troublesome linkages to the world system which limits China's ability to maneuver. A particular sore spot is the creeping domination of Manchurian markets which Japan instituted prior to their invasion in 1937. This leads the Chinese government to institute barriers to balance foreign investment and domestic control. Despite largely successful efforts to control foreign influence through tight government control of the terms of investment, the Chinese policy is undermined by its own success.

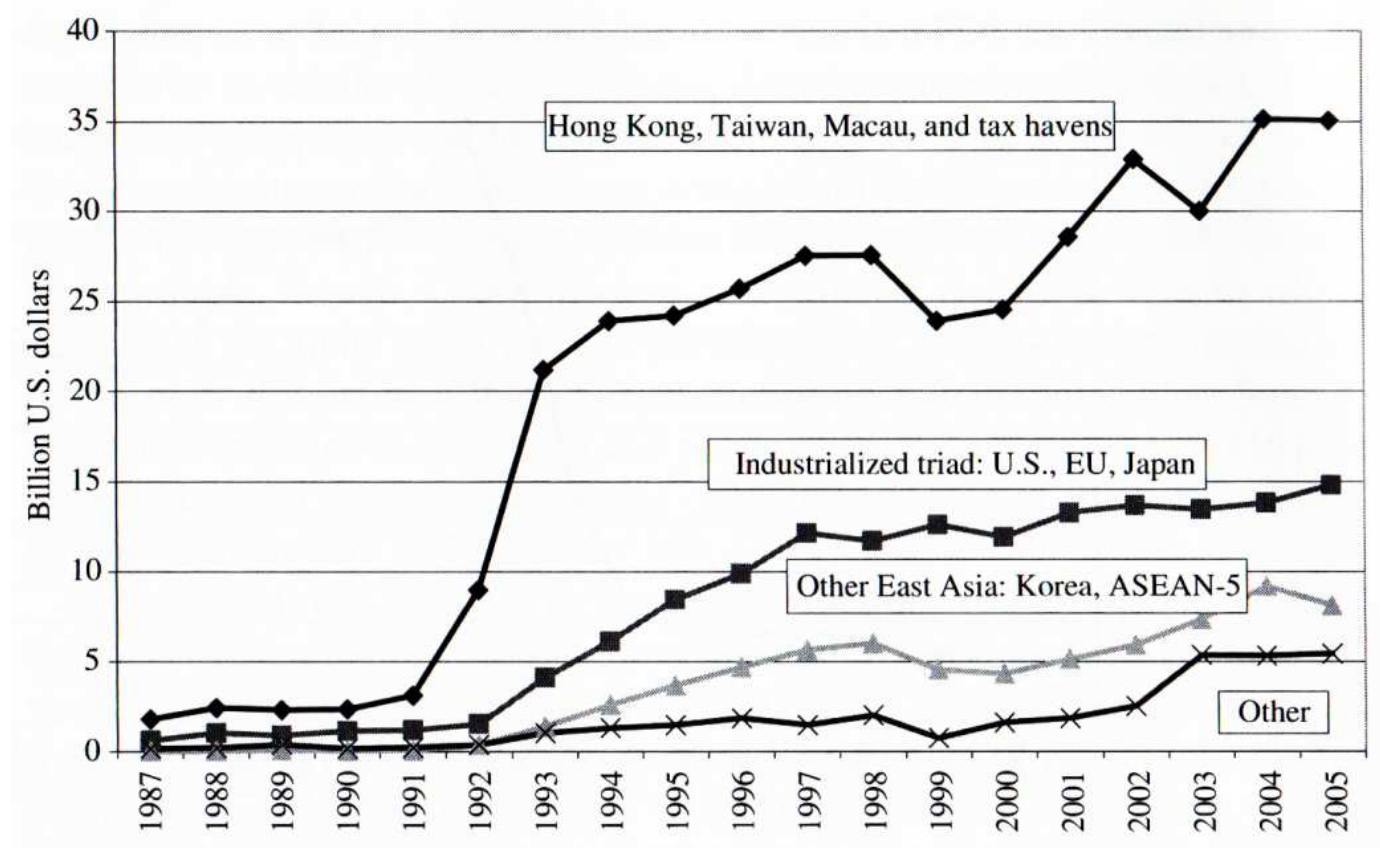

Figure 4. Main Sources of FDI to China. ${ }^{92}$

\footnotetext{
92 Ibid., 403.
} 
As opposed to utilizing stock investment or international bank loans, China has financed much of its development through FDI. Consider Figure 4 for a regional breakdown of FDI sources, with a particular eye on the investment of overseas Chinese governments and SARs. While this is avoids the meddling investor control of stock and the debt burden of development loans, it does rely on continuous foreign investor confidence. This confidence is reliant on China's stability, which is in turn linked to China refraining from aggressive actions on its myriad territorial disputes. Taiwan, the largest disputed territory and among the largest of investors in the mainland, occupies a peculiar spot in PRC foreign relations. Taiwanese business cooperation with the PRC coincides with periodic threats to Taiwanese sovereignty, such as the missile launches at the heart of the Taiwan Strait Crisis of 1996. This illustrates the murky balance struck when using economic development to stave off foreign aggression. Still, it bears repeating that full-scale conflict has been successfully avoided.

While the Senkaku Islets have enflamed public and government sentiments on multiple occasions, none has escalated into armed conflict. This is in part due to the Chinese economy's integral linkages to the world economy. That is not to say that economic cooperation creates perfect international citizens: China's recent institution of an air-defense cordon over the Senkaku Islets recalls similarly aggressive tactics during the Taiwan Straits Crisis and other disputes, but the conflict was successfully deescalated by all parties involved. 


\section{Economic Interdependence}

Given the toxic diplomatic history between China and Japan stretching to conflict over the Korean Peninsula in 663CE, the two nations make a curious trading dyad. At the same time, robust trade between China and Japan, even during periods of intense international tension, highlights the political indifference of market cooperation. Policies which back this pattern of trade being separate from international disputes are known by several names, including seikei bunri in Japan, or the separation of politics and economics.

Trade with China followed in several phases for the Japanese. In spite of the devastating and acrimonious experience of World War II, trade resumed on a small scale between the two nations in the immediate aftermath. By the 1950s and 1960s, minor private firms were engaged in bilateral trade on the per-case approval of the Chinese government. The political opening of the 1970s, culminating in the normalization of relations and the Peace and Friendship Treaty, expanded this early market cooperation. The 1980s saw the groundwork for a vastly improved trade partnership, in line with other proximal large economies. This framework blossomed into robust trading with China's emergence in the world economy in the 1990s and 2000s. ${ }^{93}$

\footnotetext{
${ }^{93}$ Stephen Robert Nagy, "Territorial Disputes, Trade and Diplomacy," China Perspectives 2013, no. 4 (December 2013): 49-57, 51.
} 


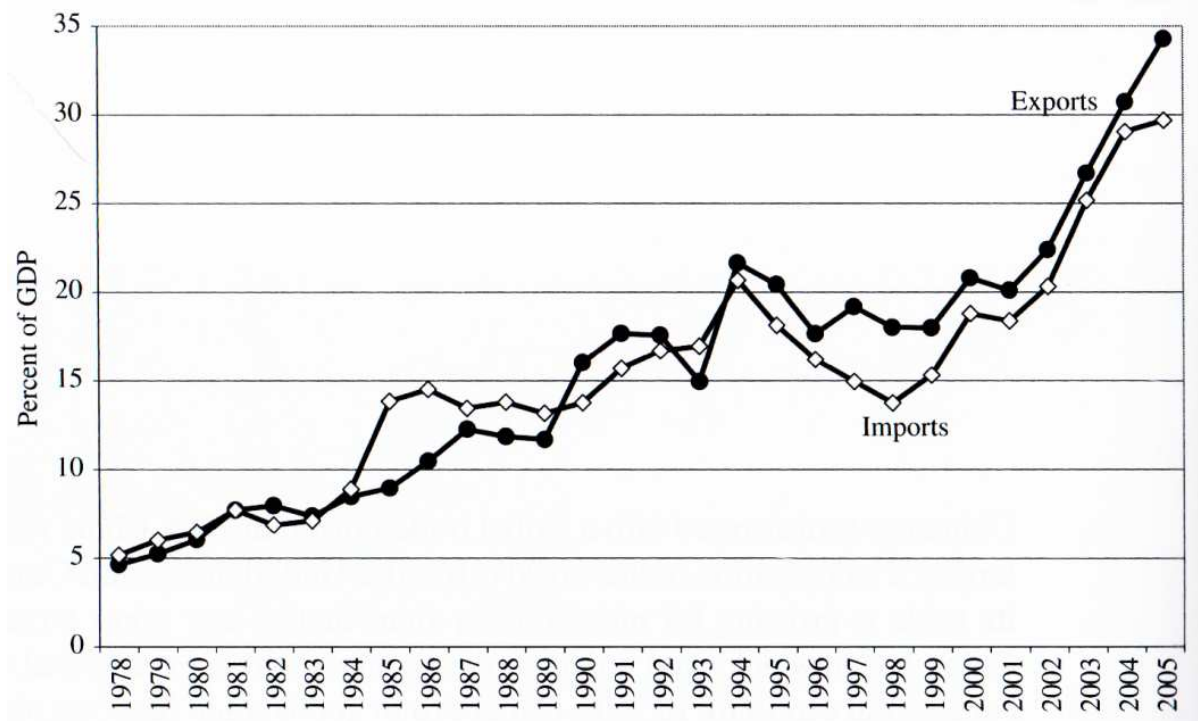

Figure 5. Total PRC Imports and Exports as Percent of GDP. ${ }^{94}$

In the past 30 years, China has experienced a transformation from an insular, largely agricultural economy to a globally interconnected industrial economy. This rapid reconfiguration is evidenced in Figure 5, as reflected in the export and import values as a share of the GDP. It bears repeating that the Chinese GDP also spiked over the same period, driven by many of the same factors, meaning that the illustrated trend is likely understated. While China is broadly dependent on international trade, with a huge and increasing portion of the national GDP developed through trade, it is also specifically wedded to trade with the Japanese in particular. The Chinese economy presently manufactures or assembles lower technology products for eventual sale by foreign companies abroad. As Japan is at the tail-end of industrial development, this arrangement is particularly beneficial as a way of reducing labor costs, which are prohibitive in the home islands. Consider the same trade statistics when charted between China and Japan over time.

\footnotetext{
${ }^{94}$ Naughton, The Chinese Economy, 378.
} 


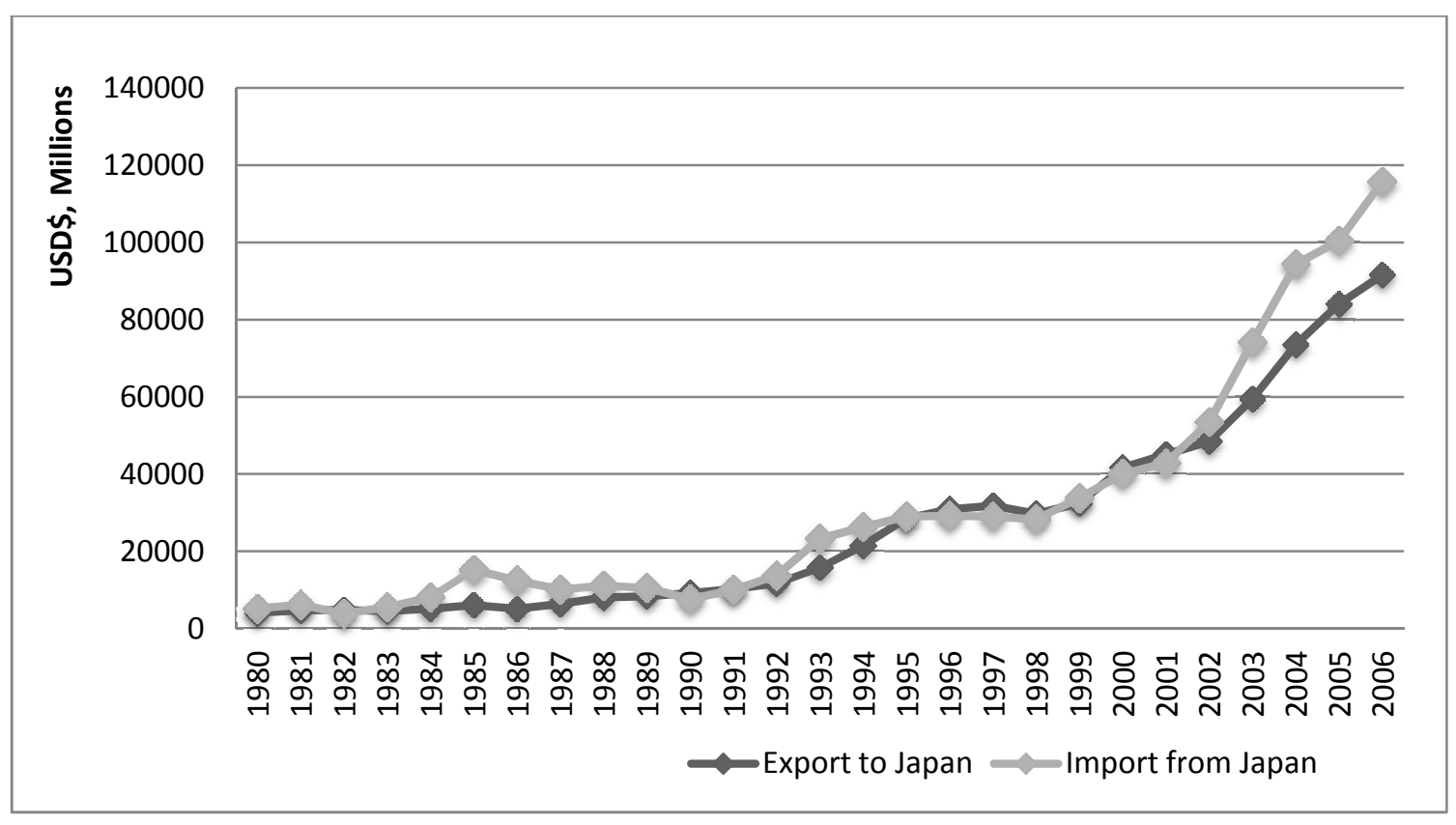

Figure 6. China's Balance of Trade with Japan. ${ }^{95}$

While Japan maintains a slight advantage in terms of total values of trade balance, the broader narrative is one of mutual benefit and growth.

When taken in the context of civil unrest and political boycotting, such as occurred in the 2012-2013 Senkaku crisis, the question of trade balance becomes important to policy formation. To understand the impetus behind state-run Chinese media sources encouraging a boycott of Japanese manufactures, an observer must understand the two countries relative dependence on one another. For instance, China might be taking an aggressive stance, ostensibly using its newfound trading might to force neighbors into concessions. Alternatively, China might be taking a defensive stance, using popular unrest as a plausibly deniable tool to protect domestic markets and reduce worrisome foreign trade dependence. Evidence more closely aligns with this latter

${ }^{95}$ Koo, "The Senkaku/Diaoyu Dispute and Sino-Japanese Political-Economic Relations," 214. 
possibility. This explanation is particularly convincing when viewed in a regime insecurity mindset, as minor reductions in total trade are not considered dangerous to home rule while foreign interference categorically is. Consider Figure 7 for a calculation of relative trade dependencies up to 2006.

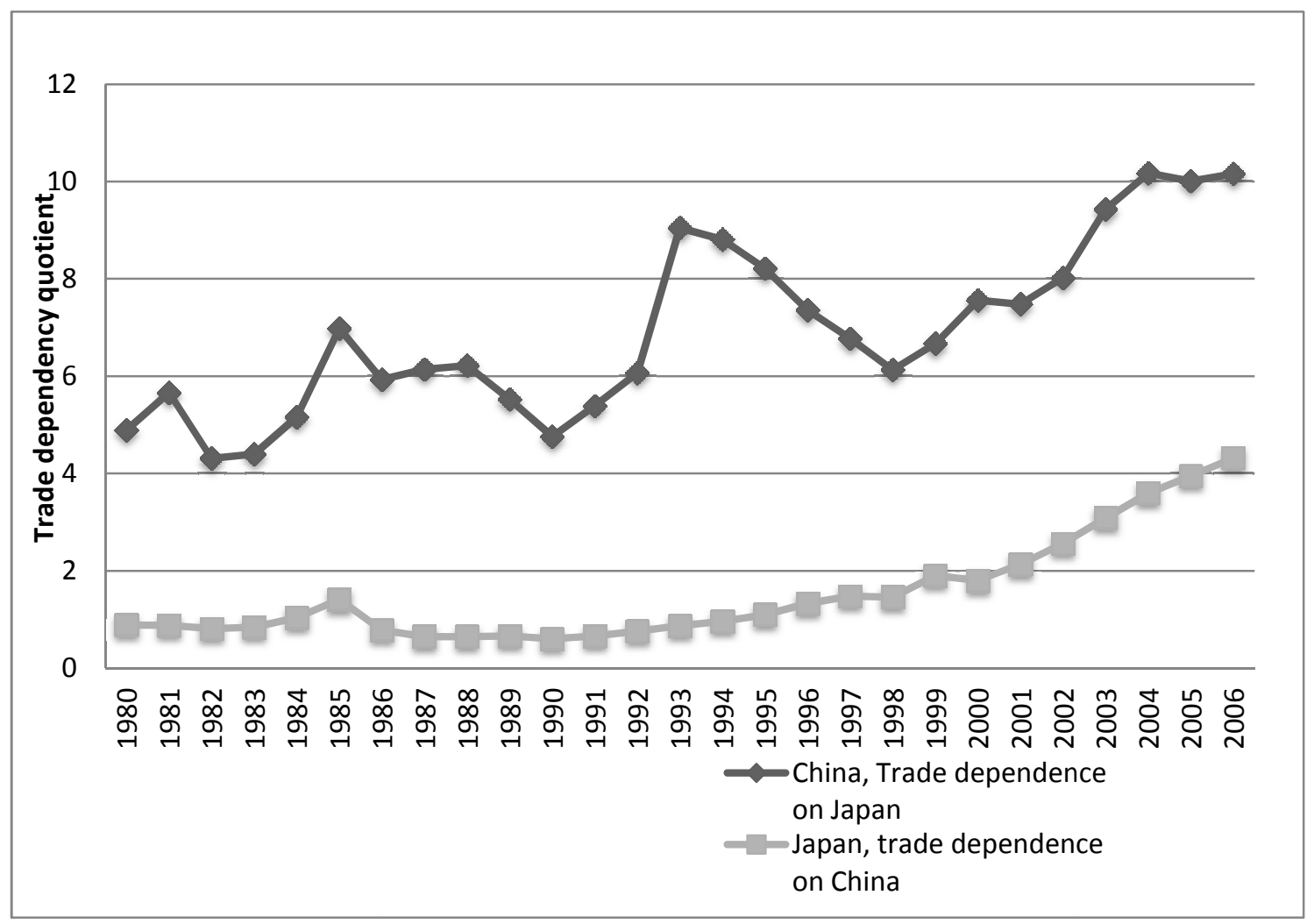

Figure 7. Trade Dependency between Japan and China. ${ }^{96}$

Trade dependency, a quotient created by Katherine Barbieri, measures the balance of trade against the size of the economy at large. ${ }^{97}$ Specifically, the calculation is formulated as a function of imports between two countries added to exports between two countries, all of which are divided by the gross domestic product of the country of

\footnotetext{
96 Ibid., 214.

${ }^{97}$ Katherine Barbieri, The Liberal Illusion?: Does Trade Promote Peace? (Ann Arbor, MI?]: University of Michigan Press, 2005).
} 
analysis. Calculating trade dependency between Japan and China renders interesting results. Contrary to the popular narrative of an economically ascendant China dominating an industrially moribund Japan, Japan has a more broadly balanced trade portfolio, and as such is insulated from shocks caused by Chinese governmental interference. When taken in conjunction with the Japanese business community's deep discomfort over recent violence on the mainland, this set of economic realities shows protests and boycotts to be counterproductive in forcing changes to Japanese island policy. If anything, further boycotting will reduce Japanese investment in the mainland without deep effect to the Japanese economy, an economically adverse proposal, but one which the central Communist leadership may be comfortable with for reasons related to domestic sovereignty. This is in keeping with the theory of regime insecurity, whereby economic success leads a regime to value internal hegemony over international cooperation when the two are at odds. The value of the overall trade, however, does appear to soften Chinese demands, as over the several decade dispute China has made no concrete effort to seize the islands by force. 


\section{CHAPTER VI POLITICAL CONTEXT}

Economic data is indicative of a nation's means, including its ability to influence or overpower its neighbors. While the economic trends of China's opening and Japan's relative decline describe a system vulnerable to upset, these trends are nothing if not acted upon. For this reason, it is important to view the economies (and the capabilities they allow) in the context of political systems. These systems will shape the actions that the concerned parties take, informed by historical recollections and economic realities.

The end of the Cold War is a vital point of reference for understanding Chinese and Japanese governance, as the fall of the Soviet Union ushered in a period of frenetic rebalancing by both powers. In Japan, the democratic system of governance that had fostered unparalleled growth in the postwar system was reformed. Clientelism was reduced, and the system was made more responsive to public opinion. All of this was done while carefully minding postwar taboos like military expansion, if not entirely foreclosing the possibility of tough stances on China and North Korea. These reforms were undertaken in the hopes of revitalizing the Japanese economy to ready it for the increase in Japan's aging population, which is itself the product of a highly successful social safety net.

China's experience since the end of the Cold War is very different. Initial uneasiness over the imbalance of global power in favor of the United States (and by 
association, the suspect Japanese) dictated early policy adjustments. Revolutionary China was characterized by abrupt and confrontational foreign policy; after the Tiananmen Square Massacre, the Communist leadership clique offered a different and subdued international response, if only to preserve the early fruits of market reform and ensure safe entrance into the WTO. Despite a conciliatory international posture, domestic violence ensured that the Chinese citizenry was clearly warned of the extents their government would go through to ensure ongoing Communist Party rule. China's relative vulnerability, however, has decreased. This transition amid massive economic growth has led to a resurgence of an aggressive, assertive China. Popular discontent, while still viciously suppressed in the domestic sphere, is encouraged when aimed outward.

\section{Japanese Politics}

Japan today is a highly functional, liberal democracy. Citizens consistently rank their nation as among the most successful in rooting out corruption, on par with the most

economically advanced OECD countries. ${ }^{98}$ Perhaps the most fundamental question facing the Japanese government in the domestic sphere is how to stoke economic development. Vast ideological differences evinced by some representative systems (i.e., the United States) are largely absent in Japanese domestic politics. Vocal minorities, such as the ultranationalist fringe, comprise an important exception to the broad trend. This system is shifting towards a more partisan configuration as a result of the electoral reforms of 1993, but the process has thus far created only moderate, incremental change.

\footnotetext{
98 "2012 Corruption Perceptions Index -- Results," accessed July 24, 2014, http://www.transparency.org/cpi2012/results.
} 
Japanese politics through the early 1990s were characterized by one-party rule with countless vying factions. The monolithic Liberal Democratic Party (LDP) dominated, and a system of clientelism was the determining factor in elections. The election structure, with a peculiar mix of proportional representation, awarded Diet seats to the top three to five candidates in district-wide elections. As a result, policy platforms need not be a broad-based appeal to a majority of voters. Elections were then fought in terms of a candidate's ability to attract pork-barrel projects to the district. ${ }^{99}$ Thus, largescale ideological issues and their attendant historical sensitivities could be avoided in typical political exchanges.

The reforms of 1993 introduced several new elements to the system. Hybridizing the existing system, a majority of Dietmen would be elected by first-past-the-post voting in single-member districts. This system, similar to the electoral system of the United States, put candidates under similar pressures to achieve district-wide appeal. A large minority of Dietmen were then elected by proportional voting, which assigned seats to political parties based on overall vote shares. The proportional mechanism, akin to many European parliamentary systems, encouraged increased party unity and discouraged sharp factional divides within parties.

The new electoral system was championed by LDP parliamentarians as a means of shoring up party support. At the time, the LDP was the largest and most stable party, while their opponents tended to be short-lived coalitions of LDP defectors. The heightened electoral competition forced parties to create partisan policy platforms, while

\footnotetext{
${ }^{99}$ Foreign Affairs, "Margarita Estévez-Abe | Shinzo Abe's Nationalist Vision | Foreign Affairs," accessed July 24, 2014, http://www.foreignaffairs.com/articles/141219/margarita-estevez-abe/feelingtriumphalist-in-tokyo.
} 
prior to the reforms candidates ran on individual client connections. ${ }^{100}$ While the LDP was able to hang on for a number of election cycles, the reforms they pursued ultimately ended their half-century of dominance as durable opposition parties were formed.

Given the new electoral rules, the impetus for forming strong and resilient political parties was renewed. Single-seat districts logically dictated that each party run only one candidate, whereas previously they had run several. While this aided the LDP by decreasing factionalism within the party, it also encouraged opposition parties to band together to increase their chances of success. As a result, opposition slowly coalesced into the Democratic Party of Japan. ${ }^{101}$ Eventually, the DPJ would outmaneuver and end the LDP dominance in the new system. This result was confirmed by the 2009 election, which marked a substantial and likely irreversible change in Japanese political life. For the first time since its inception, the Diet transferred majority rule to an opposition party.

\section{Japanese Political Parties and Factions}

Japan has seen a resurgence of conservative thinking amidst the stressors of a flagging economy, an increasingly tense regional atmosphere, and a revamped electoral system. This fact has been widely reported on in the international media, which is acutely interested in possible regional flashpoints such as the Senkaku Islets, the Spratly Islands, or the Korean Demilitarized Zone (DMZ). It is important, however, to keep these trends in context: while conservatives have headed government, notably under Abe Shinzo and Koizumi Ichiro, the changes they have implemented have been evolutionary in nature and will likely remain so.

\footnotetext{
${ }^{100}$ Sr Reed, E Scheiner, and Mf Thies, "The End of LDP Dominance and the Rise of Party-Oriented Politics in Japan," JOURNAL OF JAPANESE STUDIES 38, no. 2 (SUM 2012): 353-76, 359.

${ }^{101}$ Ibid., 361.
} 
Parallel developments have enabled conservative politicians to reach high office. Electoral reforms, designed to foster increased political responsiveness and reduce the draw of clientelist behavior, have caused a shift towards a more personally charismatic leadership. While Japanese politics are still based on reaching consensus, that consensus is increasingly negotiated between elected officials and the public rather than elected officials and the powerful bureaucracies. Public opinion, in turn, is swayed by an unstable regional balance, particularly given the region's frequent anti-Japanese outbursts. While China and North Korea pursue these policies most vigorously, South Korea and Taiwan have rounded out the group of countries that have recently denounced Japan on symbolic issues. This hostile environment gives moderate conservatives a more compelling platform to attract voters.

Starting the trend of conservative high leadership, Prime Minister Koizumi ascended to office in 2001. His ascent relied on politics by consensus, in particular drawing on a cadre of supporters from the reformist faction of the LDP. As in previous administrations, the Japanese public remained overwhelmingly concerned with domestic issues, namely economic growth and the pension system. The Koizumi administration devoted substantial amounts of political capital to addressing economic reforms. Frequently, this resulted in weakening the LDP's electoral capabilities by reducing patronage opportunities, which paved the way for the DPJ overtaking the Japanese Diet in 2009. However, Koizumi's most substantial legacy was his response to earlier electoral reforms. The Prime Minister articulated a foreign policy separated from the bureaucrats, namely Japan's career diplomatic corps. 
The Prime Minister moved to inject substantial foreign policy debate into the public dialogue. While foreign issues were not of overbearing importance to the Japanese electorate, the electoral transition enabled a more responsive debate on policy issues. This was not necessarily to Koizumi's electoral benefit: the largest issues during his administration were the deployment of Japanese military units to non-combat roles in Iraq and official visits to the Yasukuni Shrine. On neither of these issues was the Prime Minister's position popular. Koizumi's "magic," or his ability to convince the Japanese people to back otherwise unpopular maneuvers, failed to win overwhelming support for his controversial foreign affairs program. The Iraq operation concluded after two years of light casualties and intense public scrutiny, while the issue of official Yasukuni visits continues to divide the Japanese electorate. ${ }^{102}$ Just the same, he established the pattern for his successor to propose assertive and publicly debated foreign policy.

Abe Shinzo, the current Prime Minister of Japan in his second term, built on Koizumi's pattern of charismatic, conservative governance. His first term, however, lasted less than a year and ended with his party coalition in disarray. Prime Minister Abe started with high public support for his domestic, reformist agenda, seen as a continuation of Prime Minister Koizumi's LDP-based reform. However, Abe has connections to strongly contested movements within the LDP, such as earlier pushes for revision of official apologies over wartime crimes, such as the sexual abuse of Koreans during the long occupation. Additionally, Abe continued with his predecessor's stance towards Yasukuni visitations, seen as beyond the purview of foreign condemnation.

\footnotetext{
${ }^{102}$ Sheila Smith, "The Politics of Leaving the 'Postwar' Behind: Nationalism, Pragmatism and Japan's Foreign Policy," Harvard Asia Quarterly 11, no. 2/3 (2008): 95-107, 96.
} 
While domestic issues are still central to the Japanese voting public, international issues have recently figured more prominently into the electoral calculus. The crisis pitch in Sino-Japanese relations at the time of Abe's first election promoted this, pivoting on the 2006 flare-up of the Senkaku dispute, with widespread rioting that seemed to be condoned by the Chinese Communist government. Acceptance of the need for public policy debate and assertive leadership, however, should not be conflated with a broad shift towards conservatism in the Japanese electorate.

The voting public, as reported in exit polling, was indifferent to Abe's push for constitutional reform. Repeal of Article 9 of the Japanese constitution, the Peace Clause, is a consistent and elusive goal for Japanese conservatives. Even in the face of external threats, the Japanese public does not support the repeal of this central post-war feature of Japanese democracy. Consider the following survey statistics reported by Asahi Shimbun -56 percent of Japanese citizens polled oppose "exercising the right to collective self-defense," with 28 percent in favor. ${ }^{103}$ Exit polling indicated that Abe was not aided by his conservative foreign policy, but mainly that he was undone by his controversial economic reforms in the domestic sphere. ${ }^{104}$ The negative effects of these neoliberal policies were widely felt, and Abe-nomics can be seen as central in the Abe government's quick collapse.

In short, Japan has been democratically addressing a new phase of challenges since the end of the Cold War. The central theme to these challenges is the reform of the

\footnotetext{
${ }^{103}$ Asahi Shimbun, "MAJOR SECURITY SHIFT: 9\% Satisfied with Collective Self-Defense Debate; Cabinet Support Falls to 43\%," AJW by The Asahi Shimbun, accessed August 4, 2014, http://ajw.asahi.com/article/behind_news/politics/AJ201406230028.

${ }^{104}$ Ibid., 100.
} 
post-war system of governance, one which provided unprecedented prosperity but which has now faltered. Points of international contention, like the Senkaku islets, threaten to mark this reform process with increased militarism and balkanization. Certainly, elements of Japanese political leadership back the first steps toward a so-called normalized national security structure, including a standing army that can legally operate abroad. The near-total lack of success amongst conservative pushes for a more militant Japan underscores the country's political aversion to violence after the Pacific War. In changing the Japanese system, politicians and the public find a balance in utilizing and tweaking political forms from the tremendously successful post-war period, rather than harkening back to the country's disastrous imperial experience.

\section{Chinese Politics}

China today is an economically vibrant authoritarian regime. Economic success has in some ways moderated the most extreme abuses of the Communist Party, such as in the recent demobilization of forced labor camps for political and religious dissidents. ${ }^{105}$ Broad political trends within the Communist Party recognize the futility of revolutionary governance and build off the pattern of economic development espoused by Deng Xiaoping and Zhu Rongji. That being said, the nation is still defined by tight Party control over day-to-day life, from policing ordinary speech to pervasive internet monitoring. Invasive public health policies, such as the ongoing One Child Policy, insert an oppressive government into everyday life. State-media coverage works in lockstep

\footnotetext{
${ }^{105}$ NPR, Frank Langfitt, "China Ends One Notorious Form Of Detention, But Keeps Others," NPR.org, accessed August 4, 2014, http://www.npr.org/blogs/parallels/2014/02/05/271412045/china-ends-onenotorious-form-of-detention-but-keeps-others.
} 
with the leadership apparatus, a situation which leads to great difficulties in differentiating Chinese public opinion from Communist Party opinion.

Understanding the information environment in the People's Republic is key to understanding the long-term rule of the Communist Party. Chinese media is tightly circumscribed, with severe punishments and ostracization irregularly inflicted on dissident authors and editors. The result of this system is often referred to as "selfcensorship" by professional journalists, although the government also engages in direct censorship, particularly in digital media outlets. An illustrative case of PRC media regulation is that of the Southern Metropolis Daily, a newspaper which adapted aggressively to the relative openness after the fall of the Soviet Bloc. The paper was able to subvert weak party controls at the provincial level, and experienced popular success as a more-open news outlet. ${ }^{106}$ In particular, the newspaper used its editorial latitude to address endemic and unpopular corruption, tapping into popular anger on the issue. This balance worked, avoiding the retribution of the provincial Propaganda Department, but only for a time. When the paper touched on more systemic grievances against Communist Party rule, such as the detainment of those without internal travel documents or the cover-up of the SARS outbreak in the late 1990s, the Party moved in. Senior editors were arrested en masse, with several facing hefty prison sentences. ${ }^{107}$ Thus, with the extent of governmental tolerance of criticism unclear, the system requires journalists to "selfcensor" to avoid significant punishments.

\footnotetext{
${ }^{106}$ Philip P. Pan, Out of Mao's Shadow日: The Struggle for the Soul of a New China (New York City, NY]: Simon \& Schuster, 2008), 245

${ }^{107}$ Ibid., 261.
} 
Online, the system is more direct due to the advanced technical capabilities of the Chinese government. Popular global social networking and search pages, such as Twitter or Google, are blocked by sophisticated firewalls. Firewall enforced bans followed the rejection of governmental requests for access of user information, data which could allow Chinese authorities to track service users and enforce information blackouts. Equivalent services based out of the PRC, such as Sina Weibo or Baidu, accede to governmental demands for information. The government also has a nuanced command of web access within sites, both those based out of the PRC and abroad. For instance, Chinese web censors leave access to foreign media outlets intact, while blocking specific articles that reference phrases sensitive to the Communist Party. ${ }^{108}$ With this combination of capabilities, the government has an unprecedented reach into its citizens' life of the mind. Bear these systemic peculiarities in mind during our subsequent discussion of media in shaping Chinese public opinion.

For China, economic reform and political repression stem from the same root motivation: the security of the Chinese Communist Party. The end of the Cold War heralded a period of great uncertainty for China, as activists pressed for increased political autonomy internally while the Soviet Bloc collapsed. The USSR was a rival, but also a counterbalance to other rivals, namely the United States and Japan. During this period of internal vulnerability, external disputes such as the Senkaku Islets were handled gingerly. For instance, the 1996 flare-up of the crisis followed on the heels of the Tiananmen crackdown. This event, discussed prior as the Second Lighthouse Incident, was tightly moderated by the Chinese authorities. In part due to international conditions

\footnotetext{
${ }^{108}$ Richard McGregor, The Party[]: The Secret World of China's Communist Rulers (New York]: Harper, 2010), 102.
} 
and in part due to the ringleaders being from then-independent Hong Kong, the mainland suppressed news of the crisis and effectively blocked public protests. This highlights the balance between domestic and international policy in how the Chinese Communist Party views its legitimacy. In the event of domestic challenges, China responds more moderately in its international disputes.

As discussed prior, China has charted an impressive course of economic growth since the end of the Cold War. This growth has radically altered the balance of power in the region. It has also led to expectations for domestic reform that have been met with only tepid Party response. While economic success has provided an increased sense of legitimacy for Communist Party, it also highlights bankruptcies in the system. Particularly given that economic success stems from adopting a market economy, the ideological basis for rule is weak. The ubiquitous security apparatus, headed by the Ministry of Public Security, possesses the mechanisms to suppress dissent. For the general public, the Party has access to local and secret prisons, with a pliably politicized judiciary to expedite targeting government opponents. Within the Party, special investigators under the auspices of the Central Commission for Discipline Inspection pursue suspected corruption and heterodoxy, sometimes using brutal techniques. ${ }^{109}$ However, the cost of utilizing these controls is periodically high, as evidenced by the Tiananmen Massacre and the international furor that it occasioned, as well as the countless smaller scandals since. As such, the Chinese leadership clique needs more tools to enhance control than economic prosperity and an intrusive security apparatus.

\footnotetext{
${ }^{109}$ Andrew Jacobs, "Recent Cases Shed Light on China's Feared Interrogation System," The New York Times, June 14, 2012, sec. World / Asia Pacific, http://www.nytimes.com/2012/06/15/world/asia/accused-chinese-party-members-face-harshdiscipline.html.
} 
Not all tools of party control are openly coercive. The Chinese Communist Party directs vast resources, given the politicization of typically independent industries. Employment in the professoriate, media, and state-owned businesses (as well as key positions in select nominally private enterprises) is determined by the Central Organization Department. The party apparatus maintains control of these avenues of employment, and all advancement within the party, through a largely secret personnel system. ${ }^{110}$ Intense secrecy imbues the system with a number of peculiarities. As the system is opaque to outside observation, prospective dissenters are uncertain of the political boundaries that cannot be pushed before access to employment is revoked. Given that anecdotes abound of students being assigned to the far-flung provinces as retaliation against infractions, the repressive effect of central control of employment is considerable. ${ }^{111}$ Self-censorship, then, is the rational response of ambitious career candidates.

Like other remnants of revolutionary rule, the Organization Department's control over the livelihoods of millions of mainland Chinese exists in ideological limbo since the market opening. With the recession of Marxist ideology, the secrecy of the Organization Department has allowed influence peddling. The Politburo, the apex of political power, has taken keen interest in retaining secret control of top appointees through the department. This authority is critical to advancing the careers of supporters and relatives who form the factions to support high officials against ouster. Leaving these mechanisms in place for rank-and-file officials has created an opening for corruption on a vast scale.

\footnotetext{
${ }^{110}$ McGregor, The Party, 37.

${ }^{111}$ John Pomfret, Chinese Lessons: Five Classmates and the Story of the New China, 1st edition (New York: Holt Paperbacks, 2007), 168.
} 
An illuminating example, which escaped censorship as the scam was not officially endorsed, highlights the vulnerabilities of the system.

In Sichuan in 2007, when a man passing himself off as an organization department official secured a payment of $\$ 63,000$ from a local bureaucrat under the guise of finding him a senior government post. 'While they jeered at the miserable unlucky bureaucrat who paid the bribe,' the local media reported, 'people were astonished by the influence of the department over Chinese officials. ${ }^{112}$

This sort of corruption eats away at public confidence. In combination with the sometimes capricious assignment of jobs under a veil of secrecy, the department wields power at the cost of general resentment.

Territorial disputes serve a dual-purpose for the ruling elite of China. On the one hand, China can expand its resource base and international prestige by imposing its will on neighbor states. Particularly in the case of Japan, success would bring great internal legitimacy, given the linkage of the Senkaku Islets to earlier aggression in Chinese accounts. Of course, even an unrelated coup against the Japanese would likely be met with widespread popular approval, given both the enormity of imperial Japanese aggression on the continent as well the Chinese government's focus on those crimes since. On the other hand, internal challenges to power are a cause of great concern to Chinese authorities. Populist appeals to xenophobia are balanced with more direct

${ }^{112}$ McGregor, The Party, 58. 
measures of control. This is evidenced by the growth of an unprecedented security apparatus within China, including novel forms such as extensive digital monitoring. ${ }^{113}$

Without a suitable motivation, China's response to the most recent set of Senkaku crises is illogical. China has successful, if heavy-handed, mechanisms to control popular protests. This is demonstrated annually at the anniversary of the Tiananmen crackdown, with an increase in broad spectrum monitoring and even preemptive incarceration of prominent dissenters. ${ }^{114}$ When seen as politically advantageous, as in the 1996 flare-up of the Senkaku crisis, the government has the means to control even the uncommonly high popular anger over the disputed islets. In that case, however, the intervention was staged to prevent the lionization of an outsider from Hong Kong, which could have negative impacts on Communist Party legitimacy. This is a lesson well learned, as the Communist Party rose in prominence against the Chinese Nationalists by offering a more convincing rebuff to the Imperial Japanese occupation. In most cases of foreign entanglement, the Chinese government weighs the sensitivity of the global political environment versus the level of dissent against the Communist Party in China. In the most recent case, domestic legitimacy ruled.

\section{Competing Nationalists}

Following on the heels of practical annexation of the Senkaku islets by the Japanese national government, China experienced major popular protests in 85 Chinese

\footnotetext{
${ }^{113}$ Chris Buckley, “Crackdown on Bloggers Is Mounted by China," The New York Times, September 10, 2013, sec. World / Asia Pacific, http://www.nytimes.com/2013/09/11/world/asia/china-cracks-down-ononline-opinion-makers.html.

${ }^{114}$ Pan, Out of Mao's Shadow, 230.
} 
cities. ${ }^{115}$ The arc of events leading to these protests is important for understanding the various political forces which prop up the Senkaku dispute. The crisis was originally created by nationalist groups in Japan, a pattern followed by many of the Senkaku flareups. The mayor of Tokyo prefecture, Ishihara Shintaro, led a nationwide campaign fundraising to purchase the Senkaku islets from their private Japanese owner, in the hopes of gifting the islands to his prefectural government. ${ }^{116}$ His mayoral administration in Tokyo promised to aggressively defend the islets, in keeping with Japanese nationalist views on the dispute. This put the central government in an untenable position.

The national government of Japan, led by Abe Shinzo, opted to pre-empt Mayor Ishihara's nationalization. The islets being administered by Ishihara was a surefire recipe for international furor to be led by China, Japan's largest trading partner. Nationalization by the national government, however, sought to reduce one element of the agitation for China, which would be the ostensible follow-on offenses that Ishihara would likely cause. The original agitant was predictably sufficient to incense the Chinese government, and although the extent of the backlash was unprecedented, the fallout bolstered moderate conservative forces in Japan. This pattern of behavior is played on by Japanese ultranationalists. As the ultranationalists have little mainstream electoral support, they pursue theatrical agitation in the hopes of stoking a (likely disproportionate) foreign response that might increase their domestic support.

\footnotetext{
${ }^{115}$ Ian Johnson and Thom Shanker, "Anti-Japanese Protests Over Disputed Islands Continue in China," The New York Times, September 16, 2012, sec. World / Asia Pacific, http://www.nytimes.com/2012/09/17/world/asia/anti-japanese-protests-over-disputed-islands-continuein-china.html.

${ }^{116}$ Smith, "A Crisis Postponed," 27.
} 
Japanese ultranationalists are domestically unpopular for a number of reasons. Japan, like Germany, places a tremendous amount of blame for the disaster of the Pacific War on rampant nationalism. As a result, public opinion is widely ambivalent to the erosion of post-war safeguards, such as Article 9 of the Japanese Constitution. While much attention has been allotted to embarrassing equivocation on official apologies regarding abuses during the imperial occupation of Asia, the matter of war guilt is a settled issue for much of the Japanese electorate. Resistance to military involvement in the Middle East and recent protests against reinterpreting Article 9 to allow for the defense of allies highlight this uneasiness. Electorally, this puts the ultranationalists at a fundamental disadvantage.

Far-right wing groups exist outside of the mainstream political discourse for practical reasons, as well. An estimated 900 ultranationalist groups exist in Japan, with some 10,000 members under police surveillance. More than half of these organizations are thought to be fronts for the yakuza, or Japanese organized crime. ${ }^{117}$ These associations are difficult to hide, given the abrupt techniques that both groups use to exert public influence. Far-right wing groups rely on gaisensha, or sound trucks, to broadcast their political views given a lack of effective media access. These trucks take part in symbolic protests, broadcasting patriotic music and nationalist speeches. Infrequently, mainstream candidates use sound trucks to back their candidacy as well. Police do not generally interfere with the trucks as a salve to free speech, although police presence is noticeably intense and unsympathetic during anticipated protests. These noisy attempts to

\footnotetext{
117 “Old Habits Die Hard," The Economist, accessed July 24, 2014,
} http://www.economist.com/node/9205495. 
sway popular opinion are indicative of the general disenfranchisement of Japan's extreme right.

By using strategic protests, ultranationalists can broadcast their views further. As mentioned previously, groups such as the Nihon Seinensha, or the nationalist Japan Youth Federation, have jerry-rigged lighthouses on the Senkaku islets and requested official government sanction after the fact. The government is invariably hostile to their intent (for fear of proving Chinese propaganda claims of widespread militarism in Japan), but the damage is already done. The Chinese government publicly denounces the Japanese, frequently with a show of military brinksmanship. This, in turn, worries both the Japanese public and government, pressuring them to adopt a more conservative stance. This was the precise series of events followed in the most recent Senkaku flareup: Mayor Ishihara's showmanship forced the Japanese government to act, to which the Chinese government reacted threateningly, and aggressive military maneuvering by the Chinese bolsters conservative causes in Japan.

While the far-right of Japan has successfully manipulated international events, they are unable to effectively garner support to their cause. More credible conservative forces, namely in the ruling LDP coalition, forestall a rise of Japanese conservatism in the imperial mold. Both the taboo of military boosterism and the connections to organized crime relegate Japan's nationalists to the electoral fringe. While successful in goading the Chinese Communist government, which escalates the situation to shape its own domestic political environment, the Japanese ultranationalists are unable to convert media attention into a credible political force. For instance, Japan has a vibrant protest culture, largely due to faithfully enforced Freedom of Assembly protections. In the recent push to 
reinterpret Article 9 of the constitution to allow for defensive military actions overseas, over 10,000 Japanese protestors picketed Prime Minister Abe's residence. By comparison, in response to widespread anti-Japan protests in China, ultranationalists organized an anti-China protest in Tokyo. Around 50 people were reported in attendance, with many of them members of the press corps. ${ }^{118}$ So, while Japanese ultranationalists are able to trigger international incidents which further conservative causes generally, they are unable to convert that influence into popular support of their movement.

The case of Chinese nationalism is altogether more complicated. As in most avenues of life, the Chinese Communist Party intervenes substantially in public demonstrations. Public gatherings other than those sponsored by the government are highly illegal, with prominent dissidents periodically arrested on the suspicion that they might be planning to protest. ${ }^{119}$ That being said, not all protests are treated as equals. Public marches against corruption or in memorial of government abuses are quickly stifled, with participants and their families facing stern government countermeasures. Displays of anti-foreign aggression, however, are sometimes allowed space for expression. Understanding how the Chinese government views its people's nationalism as a resource and a threat is key to predicting how the government will behave.

In the most recent case, the nationalization of the Senkaku islands provoked a widespread response in the Chinese-speaking world. Mainland China had major antiJapan protests in 85 cities, with considerable violence. Icons of Japan in China were targeted by mobs of angry protestors, leading to several major manufacturers and retailers

\footnotetext{
${ }^{118}$ Eleanor Warnock, "Small Turnout for Anti-China Protest in Tokyo," WSJ Blogs - Japan Real Time, Sep 2012, http://blogs.wsj.com/japanrealtime/2012/09/18/small-turnout-for-anti-china-protest-in-tokyo/. ${ }^{119}$ McGregor, The Party, 157.
} 
to momentarily suspending operations. Even at the smallest level, Japanese-affiliated businesses suffered; Japanese restaurants, frequently owned and operated by HanChinese restaurateurs, hung Chinese national flags and boarded up their businesses to prevent damage. Drivers of Japanese-branded automobiles were in several instances dragged out of their cars and beaten, while vandalism of foreign manufactured automobiles was widespread. Protests were allowed to continue for roughly a week before the Chinese government resumed its normal strict policing of public gatherings.

That is not to say that the Chinese government was disinterested. Communicating through state-controlled media, official editorials encouraged the protests. In a signed editorial of the digital Chinese-language edition of the People's Daily, among the most official of sources available to the Chinese public, the government encouraged people to take to the streets. ${ }^{120}$ Consider the following selection from the since-removed editorial, published midweek during the height of the protests:

Defending the core interests of the motherland (the S/D islands in this case- KM) is a moral contest. In a confrontation between the righteous and unrighteous, we cannot be dragged along by the scoundrels of Japan. In globalizing, we should let the world see the peaceful rise of China, while the current government continues to improve the quality of its citizens. A great era requires a great people. The Japanese right-wing fears the most powerful Chinese people. Rational patriotism (rational frequently coded as nonviolent-KM) struggles for strong governance, carefully running the country, in order to faithfully protect the country and national dignity. ${ }^{121}$

The official narrative is encouraging to Chinese citizens on the march, bolstering routine slogans of nationalism with a call to popular action. The author encourages his readers to

\footnotetext{
${ }^{120}$ Many thanks to Tian Long for assistance and insight in translation.

${ }^{121}$ The People's Daily, “人民网评：我们怎样保卫钓鱼岛？--观点--人民网,” accessed July 24, 2014, https://archive.today/YcXm5. Translation mine.
} 
boycott Japanese goods in a rare call to civic activism. In issuing this sort of plea, the government seeks to bolster its negotiating position by pointing to popular discontent. This is only unusual in China due to the government fomenting the dissent through direct encouragement. Elsewhere in the editorial, denunciations of Japan are typically shrill. "Irrational violence," or that which is not government sanctioned, is gently rebuked. Above all, Communist leadership is emphasized as the steward of a renewed, feared Chinese nation. The direct incitement of popular unrest by the PRC government must be a potential cause for embarrassment, as the People's Daily did not translate the article and deleted it after the Chinese-language version was linked by China watchers at the New York Times.

In considering when the Chinese government allows the very real popular anger over the Senkaku dispute to boil over into public protests, a pattern emerges. On 55 occasions between 1978 and 2007, anti-Japan protests have taken place in the PRC. On 12 occasions in the same time frame, the Chinese Communist Party quashed demonstrations immediately. ${ }^{122}$ With the Senkaku islets as a frequent international agitant, the Party has the option of encouraging protests to rally its citizens around the flag, or to immediately suppress protests as a salve to international cooperation. Suppression comes with costs to legitimacy, which appears to be the Communist Party's paramount resource, and thus anti-Japan protests are rarely suppressed. This pattern will likely continue, as China's economic and military power grows relative to regional powers, the incentive toward self-restraint will be diminished. International belligerence will likely be the less costly option.

\footnotetext{
122 Jessica Chen Weiss, “Authoritarian Signaling, Mass Audiences, and Nationalist Protest in China," International Organization 67, no. 41 (January 2013): 1-35, doi:10.1017/S0020818312000380, 3.
} 
By comparison, Japanese ultranationalists are a group that the government has little incentive to interact with. Being small and viewed as unseemly in Japan and abroad, the Japanese nationalist cause cannot be successfully expressed as a mass movement. International reactions, particularly from China, are sufficiently unpredictable that the risk-adverse Japanese government does not seem eager to manipulate the ultranationalists for electoral gain. The Japanese government fumbles with its response to the nationalists, however, which ensures that China is periodically given an opportunity to vent popular unrest outwards, which it sometimes capitalizes on. With civil liberties and an independent press corps, Japan cannot afford to simply silence its ultranationalists through repression. Nor should Japan suppress its fringe extralegally, as domestic extremists are an unavoidable part of a liberal democratic system, despite that system being the bedrock which prevents the popularization of extremism.

In China, a balance is struck which uses international grievances like the Senkaku dispute as a pressure valve for popular discontent. In a somewhat open authoritarian system, repression is politically costly. Unless the international climate is especially sensitive, or the demonstrations are aimed at the domestic government, there is little incentive for an authoritarian regime to interfere initially. So it follows in China. Increasingly, China allows its public to vent popular discontent towards Japan as a salve to popular will in government decision-making. While this bolsters domestic legitimacy in China, it also increases the risk of subsequent territorial disputes: informed by a restricted body of government-sanctioned information sources, the Chinese public has fostered a severe antipathy towards the Japanese. Risk may be compounded by future 
events where the Chinese government cannot easily suppress anti-Japan protests for fear of insurrection, but cannot also act on the protestors' wishes for fear of war. 


\title{
CHAPTER VII
}

\begin{abstract}
ANALYSIS
The Senkaku Islands are not important for their own sake. Even with liberal interpretations of Exclusive Economic Zones, the economic gains that could be extracted by holding the islets are little compared to the increasing economic insecurity caused by contesting the islets. Particularly given developments in the related Chunxiao Gas Fields absent a settlement on the Senkakus, even this minor economic advantage does not hinge on legal sovereignty over the land itself. Of course, the islands are tiny and uninhabited, lending no importance to them for the purposes of protecting citizens. It is unlikely that the Chinese government would contest the issue of sovereignty at great risk for the sole purpose of reclaiming a tiny corner of its imperial antiquity. The puzzle for this study, then, is to identify the key drivers for the conflict, so that productive solutions can be proposed to curb the recent trend toward escalation.
\end{abstract}

The pronouncements of the involved parties are of little use for determining actual motivations. Escalation of the Senkaku Dispute in 2012 and 2013 led directly to a relaxation on restrictions of Japan's formidable Self-Defense Force participating in international drills, most notably with the United States Marine Corps, practicing amphibious landings on contested islands. The reinterpretation of the pacific clause of the 
Japanese constitution has likewise signaled a deepening commitment in Japanese governance to military preparedness. ${ }^{123}$ These moves toward a normalized military stance are described by Prime Minister Abe as a strategy of "proactive pacifism," which while this is an internationally supported and moderate transition, it is by no means a strategy of pacifism. The Japanese government appears increasingly prepared to defend the territorial status quo using military force, as well as aid regional allies if other territorial disputes with China spill into armed conflict.

The Chinese government's official statements are equally unhelpful for determining causes and solutions to the conflict. Given the tight media controls in place on the mainland, where Chinese leadership places an overwhelming emphasis, international pronouncements are largely unrelated to policy debates at home. At the 2014 Shangri-La Dialogue on Asian security in Singapore, the leadership of the Chinese military envoy concluded his otherwise unremarkable restatement of Chinese government policies by going off script. Lieutenant General Wang Guanzhong commented on Japan's "provocative stance" on the disputed islands, stating that China had only peaceful intentions and reserved its military force for responding to other nations' "provocations." 124 Predictably, other delegates proceeded to quiz the general, who declined to respond to most questions regarding China's many other ongoing territorial disputes. The extremely provocative air-defense cordon over the islets, which causes regular near-misses between Japanese SDF surveillance aircraft and armed Chinese

\footnotetext{
${ }^{123}$ Asahi Shimbun, "MAJOR SECURITY SHIFT: 9\% Satisfied with Collective Self-Defense Debate; Cabinet Support Falls to 43\%," AJW by The Asahi Shimbun, accessed July 24, 2014, http://ajw.asahi.com/article/behind_news/politics/AJ201406230028.

124 Asahi Shimbun, "Chinese General Slams Japan, U.S. on Final Day of Asia Security Summit," AJW by The Asahi Shimbun, accessed July 24, 2014, http://ajw.asahi.com/article/asia/china/AJ201406020042.
} 
fighters as of July 2014, goes unmentioned. We can presume that the general's comments were governmentally supported, as the English-language edition of the People's Daily substantively confirms them. ${ }^{125}$

In covering the same Shangri-La Dialogue, the People's Daily asserts that Chinese possession of the Senkaku islets stretches back 2,000 years to Han Dynasty antiquity. In an interesting rhetorical flourish, the propagandists note that no neighboring nation challenged this imperial claim until oil resources were surveyed in the region in 1971. Of course, this is a reversal of the argument that China did not contest Japanese sovereignty over the islands until oil was discovered, a more specifically backed claim that is frequently reported on in international media. As imperial antecedents are given as evidence of disputed territory, an observer would expect a host of Chinese territorial disputes. While such a body of disputes exists, it does not exist in nearly the same dimensions as suggested by China's old imperial borders, which when one includes tributary states stretched from Southeast Asia to northern edge of Siberia. As such, the stated rationale for continuing the dispute may appear more irreconcilable than the actual cause. In short, as evidenced by the lack of armed conflict up to this point, the situation is may not be as grave as it appears.

Historically, the Chinese have shown willingness to temporarily compromise on the island dispute issue once disputing the issue has served its purpose. Preceding the Fishing Expedition of the 1970s, the Chinese government had pursued Japanese cooperation in a pan-Asian front against the Soviet Union. Unable to gain external

\footnotetext{
${ }^{125}$ People's Daily, “Chinese General Reiterates Principle for Solving Island Disputes - People's Daily Online," accessed July 24, 2014, http://english.people.com.cn/n/2014/0603/c90883-8735762.html.
} 
security through diplomatic negotiations, and deeply insecure against internal challenges in the wake of Mao's death, Deng Xiaoping used the disputed islands as an opportunity to rally the fractious country around his premiership. This is an example of Chinese leadership weighing internal and external threats, in the style suggested by regime insecurity theory. Consider the question of omni-balance as the Treaty of Peace and Friendship hit early stumbling blocks. Unable to gain external protection and faced with a sudden influx of internal instability from an uncertain transfer of power, the PRC opted to raise international conflict as a cause to rally the Chinese public and Communist cadres around Deng's government.

Economic and political unrest wracked China during the First Lighthouse Incident in 1989. Japanese ultranationalists took to the islands to both bolster their support at home as well as provoke a Chinese overreaction which might further the same cause. China faced pressure on multiple fronts: Japan, then an unchallenged regional economic dynamo, was a key player in Deng Xiaoping's plan for economic revitalization. Policies had been enacted which undid the PRC's social safety net, in a process known as reform with losers. While this enabled China's later economic growth, it also triggered social unrest. Public desire for a political opening to match economic liberalization ultimately culminated in the Tiananmen Movement and massacre. The subsequent international environment was extremely hostile to the Communist government, at a moment when the PRC required foreign cooperation. As a result, the Senkaku flare-up was quickly overlooked by the PRC, demonstrating the government's pragmatism in addressing territorial compromises. 
With the fall of the Soviet Union and the rapid expansion of regional economies other than Japan, the post-Cold War period saw tremendous restructuring for Asia. The government of the PRC, just settling into a pattern of unprecedented and sustained economic growth, viewed itself as internationally insecure. Having abandoned the ideological core of communism, shown to be moribund with the fall of the USSR, Chinese party leaders faced challenges from other contenders to Chinese legitimacy. Taiwan and Hong Kong both offered governmental systems which provided the prosperity that the PRC pursued, but without the security apparatus built up over a half century of Communist rule.

The Second Lighthouse Incident in 1996 highlighted these Chinese-speaking challenges to party legitimacy, as the mainland vied with Taiwan and Hong Kong to represent territorial claims against Japan. With the death of popular Hong Kong activist David Chan in the South China Seas, the mainland leadership quickly quashed the island dispute and tightly muted any further news that would lionize the Hong Konger. The Third Taiwan Straits Crisis of 1995-96, where the PRC launched missiles into the sea adjacent Taiwan, can also be viewed in the light of stymying foreign challengers to domestic legitimacy. These events again demonstrated the central focus of PRC leadership on maintaining internal support, even where economic or territorial expansion need be sacrificed.

With its economic reforms reaching maturity, the PRC entered the twenty-first century as a rapidly developing regional heavyweight. With Russia simultaneously weakened and solicitous of better relations, there are few external military threats to the Chinese. Domestically, the story is more complicated. Rapid economic development 
builds party legitimacy by increasing standards of living, but also creates social problems such as inequality, internal migration, and corruption, all of which must be managed. While the PRC is uncommonly comfortable intervening in its citizens' private lives to stymy political unrest, there are costs to legitimacy paid for this sort of governmental intervention. The ostensible motivation for the 2005 Senkaku flare-up was the arrest of Chinese nationalists planting flags on the islets by Japanese coast guard personnel. Government controlled media in China enflamed the issue, the purpose being two-fold. First, the image of a foreign menace allowed the PRC to vent outward mounting internal dissatisfaction with the changes of economic reform. Second, natural gas technology had advanced sufficiently to allow the possibility of profitable resource extraction from the adjacent Chunxiao Gas Fields. As constant economic growth is seen as a vital component to suppressing domestic challenges to legitimacy, the Chinese government prizes values it like a strategic resource. Likely unintended, but not considered dangerous enough to suppress, public outrage over the dispute ran particularly hot. This nationalistic anger sets the tone for future territorial disputes, and suggests a problematic pattern of escalation.

The most recent Nationalization Crisis of 2012-13 gives us a troubling insight into the future. Pushed by Japanese ultranationalists attempting to purchase the disputed islets from their private owner, the Japanese government pre-emptively purchased the islets to avoid further embarrassment. At the height of its economic development, China perceived more internal threats than external, including ongoing unrest in Xinjiang and Tibet paired with a contentious integration of Hong Kong. As a result, the PRC saw little to be gained through restraining public opinion, and instead utilized its press controls to exacerbate anti-Japanese sentiments. Restrictions curtailing public gatherings went 
unenforced, and wide-spread protests ensued as citizens felt out the government's position.

To understand this most recent wave of conflict over the islands, we must consider the costs and benefits apparent to the Chinese government in pursuing the territorial dispute. The gains to domestic legitimacy are most salient. In internal Chinese military documents, the preservation of the Communist Party at the head of the government leads all other concerns, setting the Chinese apart from most governments of the world. ${ }^{126}$ It is fair to view this as a central goal of the government, and perhaps the single most emphasized goal of the government. To this end, fomenting territorial disputes is beneficial as a recurring cause to rally a diverse and restive population around the flag.

While the costs of ongoing territorial disputes are considerable, in the short term they are externalized. Diplomatic relations with the Japanese government have certainly suffered. Private businesses are voicing uncommon concerns with Chinese instability in light of the violence. As multiple nations experience similar erratic behavior interacting with the PRC, they are driven closer together, despite sharing a problematic history. Vietnam, South Korea, and the Philippines all have active territorial disputes with China, and despite having all been occupied by Japan during the Pacific War, find themselves in the same security situation vis-à-vis the aggressively expansionary China. ${ }^{127}$ This selfimposed isolation, while detrimental to the PRC's long term strategic outlook, will do

\footnotetext{
${ }^{126}$ M. Taylor Fravel, “China's Search for Military Power," Washington Quarterly 31, no. 3 (Summer 2008): 125, 127.

127 "Why Is China Isolating Itself?," The Diplomat, accessed October 11, 2014, http://thediplomat.com/2010/11/why-is-china-isolating-itself/.
} 
little to damage internal governing legitimacy. The greatest risk to that paramount resource of the CCP is that, as the dispute over the Senkaku island persists into the future, an infuriated public will demand that the government take action. In this way, the island dispute might turn from convenient propaganda into a serious issue for PRC leadership. As demonstrated in other areas, Chinese central leadership is ill-inclined to risk internal ruling legitimacy as a salve to external demands, and may be forced by popular anger to act.

Over the course of the post-Cold War period, China has sidelined its territorial ambitions to create space for economic growth without international disputes spoiling the process. True core interests, typically where large numbers of ethnic Han Chinese were in residence, formed the exception to this general rule. Deng Xiaoping was the greatest early proponent of this developmental focus, pivoting away from the ideological massmovements of Mao. Deng ensured that his protégés, able technocrats with formal preparation in economics such as Zhao Ziyang and Zhu Rongji, reached the offices of highest power in the Communist system. ${ }^{128}$ Witnessing the fall of the Soviet system, Deng saw economic growth as the only way to avoid the disastrous splintering which disempowered the Soviet bloc. He was explicit in his negotiations with the Politburo in 1991: "There is no other option open to us. If the economy cannot be boosted, over the long run, we will lose the people's support." He continued to describe the alternative to development as being "oppressed and bullied by other nations throughout the world. A

\footnotetext{
${ }^{128}$ Orville Schell and John Delury, Wealth and Power]: China's Long March to the Twenty-First Century (New York?City, NY: Random House, 2013), 290.
} 
continuation of such a situation will only lead to the collapse of the Chinese Communist Party." 129

This focus on economic development in modern Chinese international policy is best encapsulated in Deng's dictum to future leaders. The slogan taoguang yanghui, or to "avoid the limelight" until the nation was sufficiently developed to counter foreign challenges, explains a policy of increasing international assertiveness in China. As China grows by leaps and bounds, leveraging an export-oriented industrial sector with favorable currency manipulation, the importance of staying out of foreign entanglements is reduced. Particularly in the case of Japan, where a cosmology-wrecking military defeat lingers in recent memory, China is prepared for belligerence on the world stage. This trend of increased assertiveness is the best evidence for a Chinese regime overwhelmingly concerned with its hold on domestic power, a central argument of regime insecurity theory.

The impulse to safeguard domestic policy-making prerogatives is evident in China's willingness to endanger trade ties. As discussed prior, China and Japan are deeply interconnected economies. China's ascension to the World Trade Organization spurred large-scale Japanese foreign direct investment in Chinese industries. The result of this new opening was an ongoing boom in Chinese manufactures and a substantial recovery for the Japanese economy. The willingness of China to jeopardize these business relationships, given the Chinese Communist Party's evident focus on economic growth, is conspicuous. The motivation lies in the domestic power that comes from controlling the terms of economic growth. In a telling vignette, Richard McGregor

${ }^{129}$ Ibid., 319. 
describes hard-line negotiating tactics used against Mitsubishi Electric in establishing a plant outside of Shanghai. The Chinese government negotiators were willing to risk the success of the plant, and lucrative foreign investment, over the issue of Communist Party committees in the plant's organization. ${ }^{130}$ As the party committees gave the central government the ability to shut down plant operations on command (through enforced striking, for instance), a substantial measure of control was won. Investment from certain countries abroad is treated as both a resource to be exploited and a threat to be contained.

Viewing economic entanglement with the outside world as a threat has a long history in Chinese politics. Late Qing Dynasty rulers blocked foreign trade entirely, before being forced to open select treaty ports during the Century of Humiliation. Revolutionary China tightly controlled international trade, centralizing foreign interaction and trading responsibilities into vetted cadres' hands. During the initial phases of economic reform under Deng Xiaoping, Special Economic Zones controlled the geographic space for investment. Thusly, foreign contact with the Chinese public could be tightly circumscribed. These policies of limitation and control of economic intrusion demonstrate the Chinese government's perception of overseas investment. There is, however, a notable exception. From the Chinese-speaking world, investment is welcomed with relatively few barriers of trade, suggesting the governmental objection is at least in part against foreign cultures. This bipolar policy towards foreign investment fits readily within the framework of regime insecurity theory, as FDI that represents little threat to the ruling system is encouraged while investment from without is casually jeopardized.

\footnotetext{
${ }^{130}$ McGregor, The Party, 45.
} 
For instance, while Japanese FDI to China rose dramatically in the early 2000s, it paled in comparison to the investment going to mainland China from Hong Kong, Macau, and Taiwan. Of these investment sources, Hong Kong is among the largest. Given that Hong Kong was absorbed in the PRC as a Special Administrative Region (SAR) in 1997, it is only somewhat politically foreign and thus perceived as less threatening. Like the other Chinese-speaking sources of investment, Hong Kong is culturally and ethnically similar to the mainland, which leads to preferential treatment. Hong Kong's proximity to the mainland gives it substantial advantages for maneuvering in the semi-socialist market, including access to insider information ahead of competitors. Given the aforementioned government involvement in the minute operations of business, this insider access is critical. These advantages are codified in treaties as well, with the PRC offering Hong Kong SAR firms early access to industrial sectors opened up for WTO membership. ${ }^{131}$ With ready access to capital from the Chinese-speaking world, the government of the PRC has little economic incentive to preserve its relationship with Japan. This is especially true given the political distance between China and Japan, which the Chinese government views as less controllable than Hong Kong or Taiwan, both of which are within arm's reach.

One of the puzzles of the Senkaku dispute is the willingness of China to spoil its international rapport with Japan, given that the post-industrial nation is a massive prospective marketplace. Analyzing the economic development of the two countries reveals that the two nations are increasingly joined by trade ties. Japanese investment in the mainland rose rapidly in the early 2000s, and although total FDI figures are still well

\footnotetext{
${ }^{131}$ Naughton, The Chinese Economy, 415.
} 
below overseas Chinese communities, the additional influx of capital lends to China's economic dynamism. Liberal theorists predict that increasing financial ties raise the cost of conflict between two states, thus promoting cooperation and peace. Clearly, as evidenced by the sharp deterioration in relations between the two states at the height of their economic entanglement, the theory does not hold in this case. Just as the Communist Party leadership worried that poverty would loosen their hold on domestic power after the collapse of the Soviet Union, now the opposite is the case. Uncontrolled prosperity runs the risk of rendering the iron-fisted authoritarian regime obsolete, a durable key consideration of the leadership clique. Regime insecurity theory predicts this transition during times of economic growth, especially the focus on controlling disruptive internal forces and maintaining domestic power. ${ }^{132}$ Chinese leadership, with the ultimate goal of internal hegemony, takes actions that preclude high rates of Japanese investment by creating a poisonous international atmosphere. This draws on historical antecedents in Chinese governance, viewing foreign investment obligations as an undesirable compromise to domestic ruling power.

Consider the following calculations of trade dependency over the history of the Senkaku dispute. In Figure 8, trade dependency over time is charted with an overlay of major island unrest. Returning to our first hypothesis, we can see that China is more secure than ever in terms of GDP, a measure that is converted into military power and influential trade ties. This transition is followed by an increase in severity in recent Senkaku disputes, largely due to Chinese escalation. For instance, the 2005 outbreak featured substantial anti-Japanese violence in mainland protests, despite the evident

${ }^{132}$ Fravel, “Economic Growth, Regime Insecurity, and Military Strategy,” 181. 
willingness of PRC security forces to contain and control other public gatherings. In 2012 and 2013, the most disruptive disputes yet emerged, with both considerably violent protests as well as associated military posturing. Both the expansion of the aerial ADIZ as well as provocative traversing of warships in the Miyaku Straits mark an increase in military gamesmanship over the islands. Given that the most severe disruptions occurred at the height of economic growth, we can see that our first hypothesis is substantively confirmed.

Our second hypothesis addresses the role of trade in the island dispute. Recall that island incidents are classified into three categories based on the severity of conflict they entail: incidents are minor, moderate, or severe. Minor events lack violent popular protests or associated military maneuvers, moderate events include violent popular protests or military maneuvers, and the yet-to-materialize severe incident would be characterized by active warfare. We can see that the two most recent incidents fall into this moderate category, with the most recently being markedly more disruptive due to a combination of belligerent policies. The four disputes prior to 2005 were in the minor category, by comparison.

This escalation of belligerence is particularly interesting given the height of trade entanglement coinciding with the beginning of more aggressive PRC policies, such as the tolerance of anti-Japan protests and assorted types of military gamesmanship. Beginning in 2005, a sharp downward trend is observed in Chinese trade dependence on Japan. This is the product a growing Chinese economy, which reduces the importance of relatively static Japanese trade, as well as the result of worsening diplomatic ties stemming in part from the island dispute. For our second hypothesis, we can see that trade plays only a 
partially restraining role against belligerence. On the one hand, heightened trade ties appear to have discomfited the Chinese leadership and led to policies to cool economic interchange. On the other hand, armed conflict has been successfully avoided by both parties. As a result, we can measure our second hypothesis as confirmed, with the qualification that the restraint is not complete.

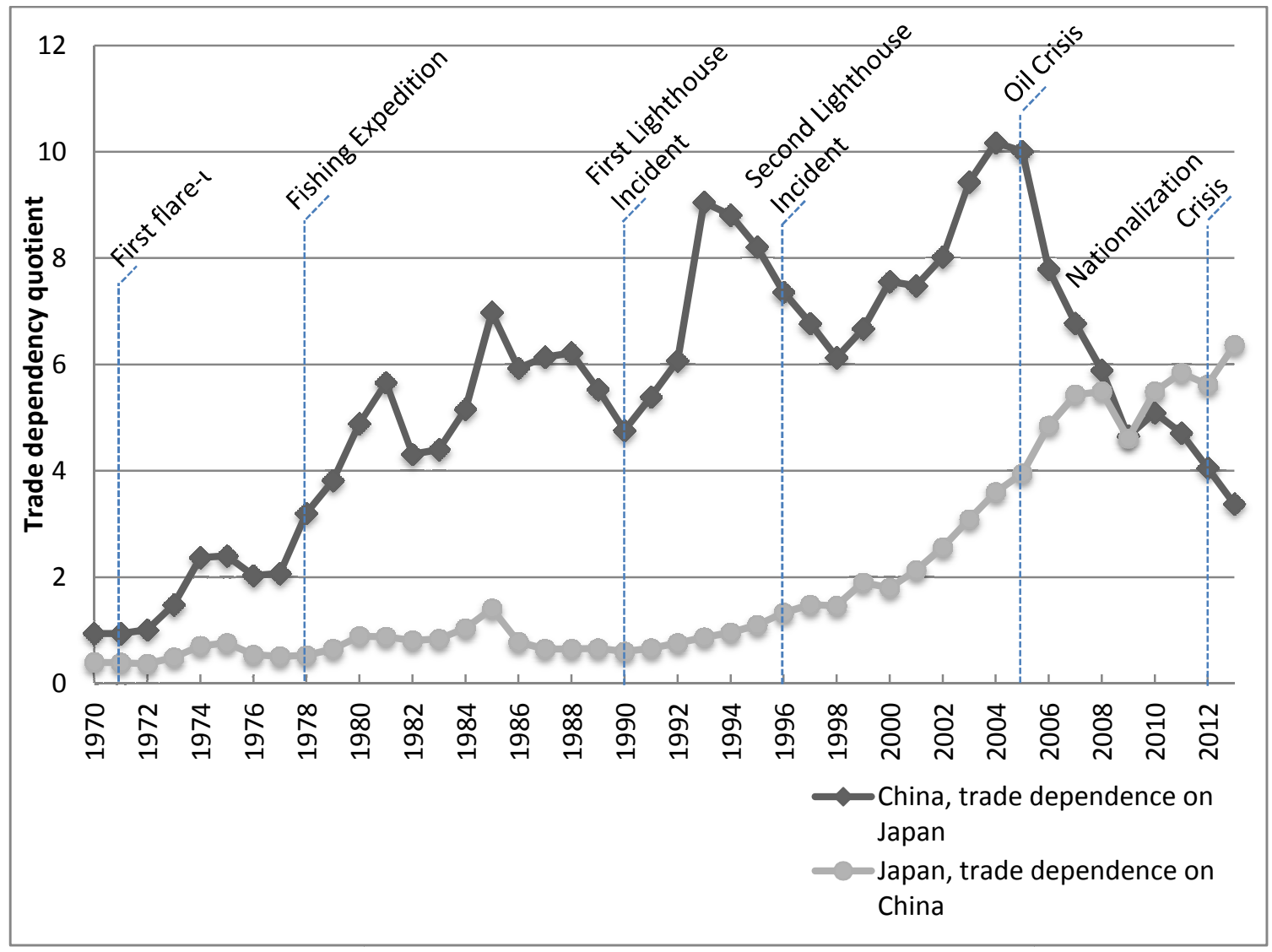

Figure 8: Trade Dependency between Japan and China Overlaid with Disputes. ${ }^{133}$

Of particular interest to our study is the inversion of trade dependency illustrated since the mid-2000s in Figure $8 .{ }^{134}$ Recall that trade dependency is calculated as the

\footnotetext{
${ }^{133}$ Koo, "The Senkaku/Diaoyu Dispute and Sino-Japanese Political-Economic Relations," 214.

134 "Trade and Investment Statistics - Reports and Statistics - JETRO," accessed October 20, 2014, http://www.jetro.go.jp/en/reports/statistics/.
} 
quotient of combined trade (imports and exports) and GDP. As Japan's GDP has remained relatively static, a mild tendency toward increased trade reliance on China is illustrated accurately. The PRC, however, has experienced substantial growth in GDP, with the effect of trade dependency calculations understating shifts in dependency. Thusly, the sharp downward trend in Chinese trade dependency on Japan is a remarkable departure from the relationship existing up to 2006. Coming so soon after a historic high point in trade in the early 2000s, the downward shift may be an intended effect of increasing pressure on the Senkaku issue.

The Senkaku dispute is thus a two-pronged tool for the Chinese government. On the one hand, by reacting strongly to Japanese ultranationalists, Chinese leadership can chill Sino-Japanese relations. This opens investment space for more politically pliable investors, limiting the potential for foreign interference and increasing internal hegemony on the mainland. The second element of the Senkaku issue is its ability to stoke Chinese nationalist sentiments. While China's increased military budget has attracted much international attention, particularly its investment in offensive deep-water capabilities aimed at challenging American naval control of the region, the domestic security budget has gone largely unnoticed. Domestic security, including capabilities used to monitor and suppress dissidents, has grown in larger portions than military funding. The issue has become acutely sensitive, with the obvious implication that the Chinese government needs intense internal security support to maintain power. As a result of public scrutiny, the government discontinued publishing complete internal security budgets in $2014 .{ }^{135}$ As imposing government through repressions entails damage to internal legitimacy, raising

\footnotetext{
${ }^{135}$ Michael Martina, "China Withholds Full Domestic-Security Spending Figure," Reuters, March 5, 2014, http://www.reuters.com/article/2014/03/05/us-china-parliament-security-idUSBREA240B720140305.
} 
the Senkaku issue presents a welcome opportunity for the PRC regime to redirect dissatisfaction outward at a low cost to its domestic standing.

In this way, incentives to manage nationalist sentiments in Japan and China are roughly the inverse of one another. For the Japanese government, ultranationalists are a costly embarrassment. Routine outbursts from small, fringe organizations endanger vital trade ties to countries such as South Korea and Taiwan. This political friction also creates the possibility of weakened alliances between the democratic powers which counterbalance mainland China. As discussed previously, the ultranationalist groups such as Ganbare Nippon and Nihon Seinensha are unable to secure substantial domestic political support. They are, however, able to use political theater to goad China into overreactions which drive mainstream political opinions in Japan towards moderate conservatism. Even so, the Japanese government's development strategy relies on international goodwill to maintain trading relationships, and thus the ultranationalists represent an unacceptable risk to collude with. Of course, Japan is a liberal democracy, and cannot simply repress its vocal minority of agitators. Nor should Japan seek to repress the ultras, as nations with open access to information can see that the nationalists represent a small portion of the Japanese people, with the majority relegating them to seedy corners of political activism.

The Chinese government faces an altogether different calculus when dealing with nationalism. With a historical legacy that focuses on threats from abroad, appeals to nationalist sentiments create a political arms race. ${ }^{136}$ Appealing to the Chinese people's

\footnotetext{
${ }^{136}$ It is worth mentioning that this historical focus on international threats is designed, reinforced by "patriotic education" programs formalized under Deng Xiaoping. Discussion of internal topics, such as The
} 
sense of historical grievance against Japan is seen as a politically less costly alternative to repression for maintaining domestic control. This manipulation of public opinion leads to several, likely unintended, consequences.

As seen in the 1990s flare-ups of the Senkaku crisis, the PRC is acutely interested in being seen as the most valid representative of Chinese national interest. If other contenders, such as Taiwan or Hong Kong, present a more robust and politically credible resistance to perceived foreign aggression, that decreases the Communist regime's domestic legitimacy. For this reason, the PRC censored the death of a Hong Kong activist attempting to land on the Senkaku islets, so as to not be outmaneuvered by a political rival. The persistence of multiple claimants reduces the ability of the PRC to back away from the Senkakus without losing legitimacy, thus constraining China's political freedom-to-maneuver. In the event of competing powers reaching political settlements with Japan, however, the Chinese motivations could change to encourage a more conciliatory posture.

Another unintended consequence of exploiting the Senkaku issue for domestic legitimacy is the difficult task of controlling nationalist anger. Under a steady diet of information focused on foreign grievances, the Chinese public has formed a substantial undercurrent of popular anti-Japanese sentiment. Protests frequently feature nasty displays of racism, such as the ubiquitous xiao riben picket signs. ${ }^{137}$ While the Chinese government made space for mass protests in 2012 by relaxing severe security restrictions

Great Famine of 1958 or the Tiananmen Movement, is forbidden. Politically comfortable history, focused on foreign aggression in recent history, is taught instead. Xenophobic nationalism is an intended side effect of this educational regime.

${ }^{137}$ A racial epithet roughly translated as "little Japs," often paired with riben guizhi, or "Japanese devils." 
on public demonstrations, the security apparatus did not need to stoke public anger over the nationalization of the Senkaku islets. Widespread popular rage was in evidence despite initially soft-spoken calls for calm from official media sources. The virulence of nationalism in mainland China represents a threat to both the control of the Communist Party over the PRC and to regional security.

Key to regional security, the military balance of power has experienced tectonic shifts in Northeast Asia. There is no common consensus on the goals of Chinese military buildup. Fravel argues that the military buildup is largely oriented towards bolstering internal security, citing amongst other evidence a sharp increase in non-combat mission briefs in declassified Chinese military journals, particularly since the Jasmine Revolution was suggested as a Chinese parallel to the Arab Spring. ${ }^{138}$ This internal focus does not reduce the possible deterrent effect of amassing military power for defensive purposes, a frequent focus of speeches by powerful figures in the PRC political chain-ofcommand. ${ }^{139}$ This view is not universally accepted, however. Pempel suggests that belligerent Chinese behavior, notably over the Senkaku islands and the expansion of territorial "core interests" to include islands disputed by other nations, presents a risk to regional security. ${ }^{140}$ These policies trigger worries that a strong economy goes hand-inhand with a hard-line security posture for China. Analysts at the Naval War College share similar concerns due to the relative wane of the Japanese economy, creating a dangerous imbalance of military power and a disincentive for the PRC to compromise. ${ }^{141} \mathrm{With}$ this

\footnotetext{
${ }^{138}$ Fravel, "Economic Growth, Regime Insecurity, and Military Strategy," 185.

139 Ibid., 183.

${ }^{140}$ Pempel, The Economy-Security Nexus in Northeast Asia, 125.

${ }^{141}$ Smith, "A Crisis Postponed," 37.
} 
theoretical disagreement in mind, let us consider forms of military might as they affect China's negotiating posture over the disputed islands.

One static factor in analyzing China's willingness to compromise in territorial disputes is land-based military might. While the People's Liberation Army (PLA) has recently surged in professionalism and technological sophistication, Chinese capabilities have remained consistently superior to nations sharing a land border and involved in territorial disputes. The one exception is along the long Russian border, where the strategic balance is also static. Rather than clear Chinese dominance, the mutual backstop of nuclear weapons and large, standing armies has created a strategic stalemate. As such, shifts in military force will likely do little to shape the behavior of claimants in landbased territorial disputes, as the basic strategic balance is locked-in for the foreseeable future. ${ }^{142}$ This military might does not ensure that the Communist regime holds all areas of the empire with equal security, as political insecurity is one of the primary drivers of military spending. It does, however, dissuade international challengers: territorial compromise with nations along the long frontier does not broadcast weakness in the PRC, which might encourage expanded claims or aggressive maneuvering amongst neighbors if they did not find the threat of force credible.

Overseas territorial disputes do not enjoy the same theoretical simplicity. China's relatively underdeveloped navy is a contributing factor to the lack of compromise evident in overseas territorial disputes. Given severe limitations to pressing international claims over blue water, Chinese leadership likely considers concessions as a possible signal of

\footnotetext{
${ }^{142}$ Fravel, "Regime Insecurity and International Cooperation," 64.
} 
weakness. ${ }^{143}$ China developing its naval capabilities creates a theoretical opening for future compromise, although the apparent purpose of China's naval expansion is near-sea dominance, more likely to be employed as a screening force for landing on Taiwan than an extremely expensive negotiating prop. ${ }^{144}$ The Chinese PLA Navy is expanding at great economic cost, with a likely aim towards adding a credible threat to already aggressive South and East China Sea posturing. The propping up of multiple island disputes fuels this pattern of naval expansion, and ultimately that trend shapes Chinese territorial negotiating prerogatives.

The balance of power in the Pacific is at present mutually beneficial enough to stem military challenges over territorial disputes, but that balance may not persist into the future. As China continues to press international claims against numerous neighbors, the government policy of using these claims as a rallying cry is likely to remain unchanged. As this creates mounting xenophobia, it will be more difficult and politically costly to countermand. Without an intervening policy change by the Chinese government, eventually this balance between stoking nationalism and accepting the territorial status quo will require an unenviable decision. Confronted with popular protests over a predictable international provocation, likely an intentional jab delivered by Japanese ultranationalists, the Chinese government will be required to suppress its population or act on the popular demands to claim the contested territory. Faced with a decision between domestic unrest and international conflict, historical precedents indicate that Chinese leadership would pay extreme prices to maintain home rule.

\footnotetext{
${ }^{143}$ Ibid., 64.

${ }^{144}$ Toshi Yoshihara and James R. Holmes, Red Star over the Pacific]: China's Rise and the Challenge to U.S. Maritime Strategy (Annapolis: Naval Institute Press, 2010.), 34.
} 


\section{CHAPTER VIII}

\section{CONCLUSIONS}

\section{Policy Recommendations}

The complexity of the Senkaku issue and the intensity of the nationalist sentiments involved have bedeviled diplomatic solutions to the crisis. In particular, the United States has shown a rare amount of indecision in announcing a position on the islands for the purpose of the mutual defense treaty. American State Department negotiators, seeing a sharp upsurge in popular anger and tending to delicate relations with allied Taiwan, hedged toward neutrality during the reversion crisis of $1971 .{ }^{145}$ In a legalistic dodge, the American stance on the islets stated that reverting territory to Japan did not acknowledge Japanese sovereignty over it. As time passed without resolution, animosities over the islands ossified. While the current American stance does not preclude peaceful negotiations over the islets, such as pursued by Taiwan, it does include the Senkaku islets under the umbrella of the US-Japanese security treaty. ${ }^{146}$ This step prevents China from misinterpreting American resolve for intervention, such as when South Korea was left outside of the announced American security cordon in the 1950s.

To peacefully defuse the Senkaku crisis, the United States should continue its policy of clearly signaling its position on the island chain. As China secures domestic

\footnotetext{
145 Smith, "A Crisis Postponed," 35.

${ }^{146}$ Andrew Quinn, "Clinton Assures Japan on Islands, Invites Abe to U.S. in February," Reuters, January 18, 2013, http://www.reuters.com/article/2013/01/18/us-japan-usa-idUSBRE90H1AX20130118.
} 
benefits by pursuing the crisis, no amount of concessions short of possession of the islets will likely improve Sino-American relations. Additionally, even during the early period of American neutrality, public media in China castigated the American position as being pro-Japanese. As such, pressuring allies into making concessions would likely be fruitless, as the PRC is independently committed to sustaining the conflict. The United States acts as a security buffer, creating space for a diplomatic settlement to be found. This may require substantial shifts within the domestic politics of the PRC, but there is reason to believe that existing trends favor moderation.

For its part, Japan has perhaps the most difficult balancing act in resolving the crisis. The Senkaku issue is tied to a handful of supremely sensitive wartime legacies. As mentioned prior, ultranationalists are a fact of political life in Japan. Rule of law and robust civil rights are a greater prize than a country free of irritating fringe political factions. However, the Japanese government could improve its reputation in East Asia and reduce the threat of constant territorial revisionism by remaining unequivocal on wartime apologies. Waffling on the classification of Korean "comfort women," for instance, needlessly endangers Japan's reconciliation with regional neighbors. This is taken in tandem with the poor treatment of Japanese citizens of Korean descent, ancestors of those affected by early-1900s Japanese colonization, which is another needlessly provocative policy that could be easily rectified to ease world opinion. Issuing an unequivocal apology, and then standing by it, would not halt international complaints of an unapologetic Japan. Media within the People's Republic of China will likely castigate Japan regardless of its substantive stances, for the aforementioned reason of stoking domestic nationalism. A standard wartime statement of contrition, in the style of the 
Kono Report, would increase Japan's moral authority on the world stage and reassure regional allies to the totality of Japan's post-war transformation.

In dealing with the Senkaku dispute specifically, Japanese diplomats have pursued a productive line of negotiations with alternate claimants. The government of Japan and Taiwan, for instance, reached a mutually beneficial island-sharing pact for the Senkaku and Diaoyutai islets in the summer of $2014 .{ }^{147}$ By defusing the tensely nationalistic situation and encouraging productive cooperation, the two democracies set a pattern for increased prosperity. Given that the islands are barren and uninhabited, this trade of concessions opens the door for greater cooperation elsewhere. Ultimately, the windfall of regional cooperation will be the far greater prize than the inhospitable islands, or even the prospect of limited oil exploration that the islands might enable. This is a study of the success of trade ties in encouraging successful cooperation, much as predicted by liberal peace theory, with the notable absence of an insecure trading partner. Collaboration with regional neighbors sets the stage for a more secure and prosperous region. Additionally, as other Chinese-speaking claimants reach settlements with Japan over collaborative use of the islands, the pressure is reduced on the Communist Party to one-up potential political rivals from abroad by presenting an aggressive front to Japan.

The People's Republic of China challenges the status quo of the Senkaku islets, as well as multiple other land and sea holdings. By aggressively pursuing these territorial claims, China isolates itself from prospective regional allies and trading partners. Given the PRC's explosive economic growth in the last two decades, its ability to peacefully

\footnotetext{
147 "Japan, Taiwan Agree on Fishing Rules in Waters around Senkakus," AJW by The Asahi Shimbun, accessed July 24, 2014, http://ajw.asahi.com/article/asia/china/AJ201401250058.
} 
influence regional and world events should be on the rise. Chinese diplomatic institutions have not yet managed to integrate this new influence in a productive manner, instead falling back on diplomatic methods reminiscent of revolutionary attack diplomacy. As demonstrated in testing our hypothesis, this routine disruption has worsened in the midst of growing trade ties. In attempting to secure its economy against Japanese interference, the Chinese leadership risks both its own economic growth and regional security by fomenting nationalism. Several academic observers on the mainland wisely identify the Senkaku islets as insufficiently valuable to warrant great risks to regional relations, and particularly to Sino-American relations. ${ }^{148}$ While the Senkaku issue may be too politically charged to resolve in the near future, the Chinese government could ease international worries by demilitarizing its dispute responses, in particular by withdrawing its warplanes from the disputed territory's airspace.

Domestically, China's preoccupation with securing Communist Party rule is leading to unintended consequences. Nationalism is used as a tool of first resort for preempting dissent, with various tools of repression as a backstop. A pliant media and tight control of information enable this marshaling of popular unrest. None of these factors are likely to persist into the future, however. The internal security budget, which includes crowd suppression and internet monitoring capabilities, has ballooned to an internationally embarrassing extent. Just more than 40 percent of Chinese citizens are currently accessing the internet, while close to double that proportion has access in Hong Kong. As the gap closes through widespread development, the government will lose manual internet censorship as one of its less-destabilizing methods of control. The anti-

\footnotetext{
${ }^{148}$ Manjiao, "The Unhelpfulness of Treaty Law in Solving the Sino-Japan Sovereign Dispute over the Diaoyu Islands," 188.
} 
Japan riots of 2012 are an outcropping of this xenophobia cultivated through information control, and while the government created and then closed the space for protest, the nationalism may not be so successfully controlled in the future.

Chinese government policy appears to recognize the threat of runaway nationalism, particularly where it endangers the Communist Party's rule at home or ability to act without constraint on the international stage. With protests being closely monitored to ensure no strains of anti-government views are being promoted, it is clear that China is concerned with overzealous mass-mobilization. Reducing the intensity of pro-Chinese nationalism is one way to mitigate the state's reliance on its security apparatus to repress dissent. Modest reforms to education, such as modernization and moderation of "patriotic education," have been piloted in Shanghai. ${ }^{149}$ If expanded to the rest of the country, China may begin to reduce its unhealthy reliance on fear of outsiders as a rallying political force. While this will not resolve the root territorial disputes, it will help stabilize the region so that those disputes will see peaceful and mutually acceptable resolutions.

\section{Openings for Future Research}

In analyzing East Asian territorial disputes, a diversity of approaches yields the most comprehensive understanding of the underlying issues. In particular, the economic element offers important insights into the motivations of the involved parties, which as discussed previously, can be difficult to interpret. An interesting contradiction in the economic material is the stated goal of the Japanese government, and in particular its

\footnotetext{
${ }^{149}$ Joseph Kahn, "Where's Mao? Chinese Revise History Books," The New York Times, September 1, 2006, sec. International / Asia Pacific, http://www.nytimes.com/2006/09/01/world/asia/01china.html.
} 
Ministry of Foreign Aid, of using aid and trade to bolster relations with foreign countries such as the PRC. Further study of the relation between increasing economic cooperation and its role in dispute management could aid the Japanese government in tailoring policies that successfully encourage reciprocal cooperative behavior in the region.

Considered at the periphery of this study, the system of "patriotic education" in China likely also has a large impact on ongoing disputes between China and her neighbors. A consideration of the development of educational materials over time would lend important insight into information sources feeding into popular anti-foreign sentiment, and anti-Japanese sentiment in particular. As records become available regarding Politburo meetings setting the "patriotic education" system in motion, an evidentiary basis for analysis of policy will become clear. The result of that policy can be viewed in the documents set forth as textbooks or supplementary readings to school students. Finally, polling data would be ideal for tracking the effect of policy and execution, but would not likely be permitted by the mainland government. The first two stages of analysis might offer valuable insight into nationalism on the mainland, regardless.

\section{Summary}

The dispute over the Senkaku islands is a challenge to regional security and a stumbling block for greater economic and diplomatic cooperation in East Asia. Despite a resolution being in all parties' ultimate best interest, rogue nationalist factions and shortterm political expedients prevent a satisfactory conclusion. In this stalled diplomatic environment, routine policies of anti-foreign agitation by the Communist Chinese 
government reach toward destabilizing proportions. While the dispute is unlikely to boil over into large-scale armed conflict, it does limit both Japan's and particularly China's freedom to maneuver and compromise. Given sufficient time under present conditions, the PRC's delaying and propagandizing tactics may lead to critical regional tension in an already delicate East Asian political environment.

In discussing the historical, economic, and political factors propelling the island dispute, we have aimed to offer a compelling vision of the nuanced security dilemma of East Asia. Historical questions, set in motion by the calamity of the Pacific War, which radically reordered the lives of hundreds of millions of people, remain unresolved. A renaissance in economic development, led at first by Japan and now increasingly driven by Chinese growth, has yet to be matched by new modes of diplomatic interaction. Particularly as China struggles to redefine itself after communism, stubbornly refusing substantial political reforms toward a less authoritarian state, internal stability in the great powers becomes a question of regional security. The United States, for its part, seeks to stabilize the region and force a diplomatic solution by throwing military might behind the status quo. Hopefully, this policy will continue into the future, creating space for the contesting parties to reach an amiable solution. Ultimately, however, this task will be reserved for the parties themselves. The successful reordering of Asia after the Pacific War remains an open question, and its peaceable conclusion will be one of the great measures of the new global system's stability and worth. 


\section{REFERENCES}

“2012 Corruption Perceptions Index -- Results.” Accessed July 24, 2014. http://www.transparency.org/cpi2012/results.

Armstrong, Shiro P. "The Politics of Japan-China Trade and the Role of the World Trade System." World Economy 35, no. 9 (September 2012): 1102-20. doi:10.1111/j.1467-9701.2012.01473.x.

Barbieri, Katherine. The Liberal Illusion $\square$ : Does Trade Promote Peace?. Ann Arbor, MI $\square$ : University of Michigan Press, 2005.

Buckley, Chris. "Crackdown on Bloggers Is Mounted by China." The New York Times, September 10, 2013, sec. World / Asia Pacific.

http://www.nytimes.com/2013/09/11/world/asia/china-cracks-down-on-onlineopinion-makers.html.

"China Imposes Restrictions on Air Space Over Senkaku Islands." The Diplomat. Accessed October 12, 2014. http://thediplomat.com/2013/11/china-imposesrestrictions-on-air-space-over-senkaku-islands/.

“China Sends Warplanes to Air Zone.” BBC News. Accessed July 24, 2014. http://www.bbc.com/news/world-asia-china-25144465.

"Chinese General Reiterates Principle for Solving Island Disputes" The People's Daily Online. Accessed July 24, 2014. http://english.people.com.cn/n/2014/0603/c90883-8735762.html.

"Chinese General Slams Japan, U.S. on Final Day of Asia Security Summit." AJW by The Asahi Shimbun. Accessed July 24, 2014. http://ajw.asahi.com/article/asia/china/AJ201406020042.

Chiozza, Giacomo, and H. E. Goemans. "Peace through Insecurity: Tenure and International Conflict." The Journal of Conflict Resolution, 2003.

“China's Nuclear Tests.” The Center for Nuclear Studies. Accessed July 24, 2014. http://cns.miis.edu/archive/country_china/coxrep/testlist.htm.

"Country and Region Specific Forecasts and Data.” Accessed October 12, 2014. http://www.worldbank.org/en/publication/global-economic-prospects/data.

Danilovic, Vesna, and Joe Clare. "The Kantian Liberal Peace (Revisited)." American Journal of Political Science 51, no. 2 (April 2007): 397-414. doi:10.1111/j.15405907.2007.00258.x.

Doyle, Michael W. "Three Pillars of the Liberal Peace." The American Political Science Review, 2005. 
Fravel, M. Taylor. “China’s Search for Military Power.” Washington Quarterly 31, no. 3 (Summer 2008): 125.

. "Economic Growth, Regime Insecurity, and Military Strategy: Explaining the Rise of Noncombat Operations in China." Asian Security 7, no. 3 (September 2011): 177-200. doi:10.1080/14799855.2011.615080.

. "Regime Insecurity and International Cooperation: Explaining China's Compromises in Territorial Disputes." International Security, 2005.

Gao Jianjun. "The Territorial Status of the Diaoyu Islands in 1895: A Crucial Issue for the Dispute over These Islands." Social Sciences in China 31, no. 4 (November 2010): 106-17. doi:10.1080/02529203.2010.534677.

Hane, Mikiso. Eastern Phoenix $\square$ : Japan since 1945. Boulder, CO $\square$ : Westview Press, 1996.

Hughes, Christopher R. "Japan in the Politics of Chinese Leadership Legitimacy: Recent Developments in Historical Perspective." Japan Forum 20, no. 2 (July 2008): 245-66. doi:10.1080/09555800802047517.

Jacobs, Andrew. "Recent Cases Shed Light on China's Feared Interrogation System." The New York Times, June 14, 2012, sec. World / Asia Pacific. http://www.nytimes.com/2012/06/15/world/asia/accused-chinese-party-membersface-harsh-discipline.html.

"Japan | Data." Accessed July 24, 2014. http://data.worldbank.org/country/japan.

"Japan Complains over China Drill Rig." BBC News. Accessed July 24, 2014. http://www.bbc.com/news/world-asia-23159436.

“Japan PM Condemns China Radar Act.” BBC News. Accessed July 24, 2014. http://www.bbc.com/news/world-asia-21347915.

"Japan, Taiwan Agree on Fishing Rules in Waters around Senkakus." AJW by The Asahi Shimbun. Accessed July 24, 2014. http://ajw.asahi.com/article/asia/china/AJ201401250058.

Johnson, Ian, and Thom Shanker. "Anti-Japanese Protests Over Disputed Islands Continue in China." The New York Times, September 16, 2012, sec. World / Asia Pacific. http://www.nytimes.com/2012/09/17/world/asia/anti-japanese-protestsover-disputed-islands-continue-in-china.html.

Kahn, Joseph. "Where's Mao? Chinese Revise History Books." The New York Times, September 1, 2006, sec. International / Asia Pacific. http://www.nytimes.com/2006/09/01/world/asia/01china.html.

Kissinger, Henry. On China. New York City, NY $\square$ : Penguin Press, 2011.

Koo, Min Gyo. "The Senkaku/Diaoyu Dispute and Sino-Japanese Political-Economic Relations: Cold Politics and Hot Economics?" Pacific Review 22, no. 2 (May 2009): 205-32. doi:10.1080/09512740902815342.

Langfitt, Frank. "China Ends One Notorious Form Of Detention, But Keeps Others." NPR.org. Accessed August 4, 2014. http://www.npr.org/blogs/parallels/2014/02/05/271412045/china-ends-onenotorious-form-of-detention-but-keeps-others.

Lee, Chae-Jin. "The Making of the Sino-Japanese Peace and Friendship Treaty." Pacific Affairs, 1979. 
"Major Security Shift: 9\% Satisfied with Collective Self-Defense Debate; Cabinet Support Falls to 43\%." AJW by The Asahi Shimbun. Accessed August 4, 2014. http://ajw.asahi.com/article/behind_news/politics/AJ201406230028.

Manicom, James. Bridging Troubled Waters $\square$ : China, Japan, and Maritime Order in the East China Sea. Washington, DC $\square$ : Georgetown University Press, 2014.

Manjiao, Chi. "The Unhelpfulness of Treaty Law in Solving the Sino-Japan Sovereign Dispute over the Diaoyu Islands." East Asia Law Review 6 (October 1, 2011): 163.

Mansfield, Edward D., Helen V. Milner, and B. Peter Rosendorff. "Free to Trade: Democracies, Autocracies, and International Trade." The American Political Science Review, 2000.

"Margarita Estévez-Abe | Shinzo Abe's Nationalist Vision | Foreign Affairs." Accessed July 24, 2014. http://www.foreignaffairs.com/articles/141219/margarita-estevezabe/feeling-triumphalist-in-tokyo.

Martina, Michael. "China Withholds Full Domestic-Security Spending Figure." Reuters. March 5, 2014. http://www.reuters.com/article/2014/03/05/us-china-parliamentsecurity-idUSBREA240B720140305.

McGregor, Richard. The Party $\square$ : The Secret World of China's Communist Rulers. New York City, NY $\square$ : Harper, 2010.

"MOFA: Joint Communique of the Government of Japan and the Government of the People's Republic of China.” Accessed July 24, 2014. http://www.mofa.go.jp/region/asia-paci/china/joint72.html.

Moravcsik, Andrew. "Taking Preferences Seriously: A Liberal Theory of International Politics." International Organization, 1997.

Mushkat, Roda. "Chinese Border Disputes Revisited: Toward a Better Interdisciplinary Synthesis." Richmond Journal of Global Law and Business, no. 1 (2012): 45.

Nagy, Stephen Robert. "Territorial Disputes, Trade and Diplomacy." China Perspectives 2013, no. 4 (December 2013): 49-57.

Naughton, Barry. The Chinese Economy $\square:$ Transitions and Growth. Cambridge, MA $\square$ : MIT Press, 2007.

Newbrander, David. "Liberal Peace: A Dyad of Democracy and Economic Interdependence, Grounded in Agent Desires." The Monitor Journal of International Studies 18, no. 1 (2012).

“Old Habits Die Hard." The Economist. Accessed July 24, 2014. http://www.economist.com/node/9205495.

Pan, Philip P. Out of Mao's Shadow $\square$ : The Struggle for the Soul of a New China. New York City, NY: Simon \& Schuster, 2008.

Pempel, T. J. The Economy-Security Nexus in Northeast Asia. Routledge, 2013.

Pomfret, John. Chinese Lessons: Five Classmates and the Story of the New China. 1st edition. New York City, NY: Holt Paperbacks, 2007.

Posner, Eric. "Why Are China and Japan Inching Toward War Over Five Tiny Islands?" Slate, February 25, 2014.

http://www.slate.com/articles/news_and_politics/view_from_chicago/2014/02/the _senkaku_or_diaoyu_islands_where_world_war_iii_could_start_because_of.html. 
Quinn, Andrew. "Clinton Assures Japan on Islands, Invites Abe to U.S. in February." Reuters. January 18, 2013. http://www.reuters.com/article/2013/01/18/us-japanusa-idUSBRE90H1AX20130118.

Reed, S., E. Scheiner, and M. Thies. "The End of LDP Dominance and the Rise of PartyOriented Politics in Japan." Journal of Japanese Studies 38, no. 2 (SUM 2012): $353-76$.

Roberts, J.A.G. A History of China. Palgrave Essential Histories. New York City, NY: Palgrave Macmillan, 2011.

Schell, Orville, and John Delury. Wealth and Power $\square$ : China's Long March to the Twenty-First Century. New York City, NY $\square$ : Random House, 2013.

Smith, Paul J. "A Crisis Postponed." Naval War College Review 66, no. 2 (Spring 2013): $27-44$.

Smith, Sheila. "The Politics of Leaving the 'Postwar' Behind: Nationalism, Pragmatism and Japan's Foreign Policy." Harvard Asia Quarterly 11, no. 2/3 (Spring 2008): 95-107.

Snyder, Qz. "The Illiberal Trading State: Liberal Systemic Theory and the Mechanism of Socialization." Journal of Peace Research 50, no. 1 (January 2013): 33-45.

Swaine, Michael D. "Chinese Views Regarding the Senkaku/Diaoyu Islands Dispute." China Leadership Monitor, no. 41 (Spring 2013): 1.

"The Memory Of Tiananmen | The Tank Man | FRONTLINE | PBS.” Accessed July 24, 2014. http://www.pbs.org/wgbh/pages/frontline/tankman/cron/.

"Trade and Investment Statistics - Reports and Statistics - JETRO." Accessed October 20, 2014. http://www.jetro.go.jp/en/reports/statistics/.

"US Bombers Challenge China's Air Defense Identification Zone." The Diplomat. Accessed October 12, 2014. http://thediplomat.com/2013/11/us-bomberschallenge-chinas-air-defense-identification-zone/.

Wacziarg, Romain, and Karen Horn Welch. Trade Liberalization and Growth $\square:$ New Evidence. NBER Working Paper Series: No. 10152. Cambridge, MA $\square$ : National Bureau of Economic Research, 2003.

Warnock, Eleanor. "Small Turnout for Anti-China Protest in Tokyo." WSJ Blogs - Japan Real Time, Sep 2012. http://blogs.wsj.com/japanrealtime/2012/09/18/smallturnout-for-anti-china-protest-in-tokyo/.

Weiss, Jessica Chen. "Authoritarian Signaling, Mass Audiences, and Nationalist Protest in China." International Organization 67, no. 41 (January 2013): 1-35. doi:10.1017/S0020818312000380.

"Who Really Owns the Senkaku Islands?" The Economist, December 3, 2013. http://www.economist.com/blogs/economist-explains/2013/12/economistexplains-1.

“Why Is China Isolating Itself?” The Diplomat. Accessed October 11, 2014. http://thediplomat.com/2010/11/why-is-china-isolating-itself/.

Yang, Jisheng, Edward Friedman, Jian Guo, and Stacy Mosher. Tombstone $\square$ : The Great Chinese Famine, 1958-1962. New York City, NY $\square$ : Farrar, Straus and Giroux, 2013.

Yoshihara, Toshi, and James R. Holmes. Red Star over the Pacific $\square$ : China's Rise and the Challenge to U.S. Maritime Strategy. Annapolis, MD $\square$ : Naval Institute Press, 2010. 
Zhongqi Pan. "Sino-Japanese Dispute over the Diaoyu/Senkaku Islands: The Pending Controversy from the Chinese Perspective." Journal of Chinese Political Science 12, no. 1 (March 2007): 71-92. doi:10.1007/s11366-007-9002-6.

“人民网评：我们怎样保卫钓鱼岛？--观点--人民网.” Accessed July 24, 2014. https://archive.today/YcXm5 